\title{
T Cell Receptor Profiling in Type 1 Diabetes
}

\author{
Laura M. Jacobsen ${ }^{1}$ - Amanda Posgai ${ }^{2} \cdot$ Howard R. Seay ${ }^{2} \cdot$ Michael J. Haller $^{1}$ • \\ Todd M. Brusko ${ }^{2}$
}

Published online: 11 October 2017

(C) The Author(s) 2017. This article is an open access publication

\begin{abstract}
Purpose of Review The genetic susceptibility and dominant protection for type 1 diabetes (T1D) associated with human leukocyte antigen (HLA) haplotypes, along with minor risk variants, have long been thought to shape the T cell receptor (TCR) repertoire and eventual phenotype of autoreactive $\mathrm{T}$ cells that mediate $\beta$-cell destruction. While autoantibodies provide robust markers of disease progression, early studies tracking autoreactive $\mathrm{T}$ cells largely failed to achieve clinical utility.

Recent Findings Advances in acquisition of pancreata and islets from T1D organ donors have facilitated studies of T cells isolated from the target tissues. Immunosequencing of TCR $\alpha / \beta$-chain complementarity determining regions, along with transcriptional profiling, offers the potential to transform biomarker discovery.

Summary Herein, we review recent studies characterizing the autoreactive TCR signature in T1D, emerging technologies, and the challenges and opportunities associated with tracking TCR molecular profiles during the natural history of T1D.
\end{abstract}

This article is part of the Topical Collection on Pathogenesis of Type 1 Diabetes

Todd M. Brusko

tbrusko@ufl.edu

1 Department of Pediatrics, College of Medicine, University of Florida Diabetes Institute, Gainesville, FL, USA

2 Department of Pathology, Immunology and Laboratory Medicine, College of Medicine, University of Florida Diabetes Institute, Gainesville, FL, USA
Keywords T cell receptor · Immunosequencing · Type 1 diabetes · Human immune repertoire - Adaptive immunity · Autoimmunity

\section{Introduction}

Abundant evidence in animal models support the central role $T$ cells play in the adaptive immune-mediated killing of pancreatic $\beta$-cells in type 1 diabetes (T1D) [1-4]. This direct pathogenic role is corroborated by bone marrow and adoptive cell transfers in both non-obese diabetic (NOD) mice and patients [5-8], along with $\mathrm{T}$ cell receptor (TCR) transgenic models [9]. Yet, key differences have been noted in the prominent lymphocytic infiltrate present in the NOD mouse in comparison to the variable and often sparse insulitis observed in the pancreas of organ donors with T1D [10, 11]. These differences have prompted extensive efforts to further investigate disease mechanisms and the nature of the autoreactive response in human beings [10-14]. The capacity to acquire tissues directly from pancreas and islets of organ donors with T1D has provided a unique opportunity to study tissueresident lymphocytes and elucidate their phenotype and molecular signature.

The search for biomarkers of T cell autoreactivity in T1D has largely been driven by efforts to identify $\mathrm{T}$ cell peptide epitopes derived from antigens recognized by autoantibodies $[15,16]$. These studies have employed MHC-multimers, ELISpot, and $\mathrm{T}$ cell dye dilution assays, among others [17-19]. A significant number of clones and TCR reactivities have emerged; however, the adoption of bioassays to track autoreactive $T$ cells has largely remained restricted to individual investigator laboratories. The lack of widespread adoption of such assays likely results from both biological and technical limitations [i.e., requirements for significant numbers of 
viable peripheral blood mononuclear cells (PBMC) and assays based on specific human leukocyte antigen (HLA) haplotypes]. Moreover, the antigen specificity of the TCR is thought to direct and retain $\mathrm{T}$ cells within defined tissues and draining lymph nodes (LN) [20-22], making the circulating frequency of autoreactive T cells exceptionally low-estimated at less than $0.05 \% \mathrm{CD}^{+} \mathrm{T}$ cells $[23 \cdot]$ and $0.01 \%$ of $\mathrm{CD} 8^{+} \mathrm{T}$ cells $[24,25]$. This low frequency restricts the numbers of antigens and epitopes available for analysis and requires considerable volumes for current assays, a notable limitation in pediatric patients. To address some of these limitations and further explore the potential of TCR repertoire analysis, we along with others have begun to employ immunosequencing of TCRs to identify $\mathrm{T}$ cell biomarkers with a high level of sensitivity and specificity. With this review, we summarize current progress in the field of $\mathrm{T}$ cell sequencing technologies, the potential for novel biomarker discovery, and the application of this knowledge base toward developing new therapies to cure $T$ cell-mediated autoimmune diseases, with a specific focus on T1D.

\section{Role for Autoreactive T Cells in T1D Pathogenesis}

\section{Dominance of HLA Risk}

The HLA-DR3/DR4-DQ8 haplotype carries the highest risk for progression to T1D [26]. HLA molecules shape the developing TCR repertoire during thymic selection. Developing T cells integrate signals from recombination events resulting in fate determinations to the TCR $\gamma / \delta$ or $\alpha / \beta$ lineage. Among the $\alpha / \beta$ TCR lineage, positive and negative selection events further shape the repertoire including the emergence of thymicderived regulatory $\mathrm{T}$ cells (tTreg), which are necessary to establish peripheral immune tolerance [27]. Approximately 57 genetic loci identified by genome-wide association studies (GWAS) (e.g., PTPN22, CD25, SH2B3, IFIH1, CD226, etc.), each with low individual odds ratios, are thought to provide additional risk besides HLA, by promoting innate inflammation, leading to altered immune cell signaling, and augmenting $\beta$-cell stress, ultimately resulting in a failure in immune tolerance [28]. Importantly, HLA haplotypes and other susceptibility alleles are carried at varying frequencies in different ethnic groups. Even among groups with similar background genetics, geographic exposures may result in highly variable disease penetrance. Combinations of alleles can also provide dominant protection, as noted for DQB1*06:02 in Caucasians as well as DPB1 polymorphisms in non-Caucasian ethnicities [29, 30]. Moving forward, it will become important to understand both the impact of allelic frequencies and the role of environmental exposures in determining the diversity and specificity of the TCR repertoire in various T1D cohorts.

\section{T Cell Studies in nPOD and Following Pancreatic Transplant}

Over the past decade, the Network for Pancreatic Organ donors with Diabetes (nPOD) program has facilitated investigations of the T1D pancreas across a wide range of donor ages, races, and T1D disease durations [31]. The insulitis lesion that histologically characterizes T1D is much less fulminant in the human pancreas than in the NOD mouse [32, 33]. Human insulitis has been shown to include macrophages, natural killer (NK) cells, B cells, and $\mathrm{CD}^{+} \mathrm{T}$ cells, with a predominance of $\mathrm{CD} 8^{+}$relative to $\mathrm{CD} 4^{+} \mathrm{T}$ cells. A relationship between this $\mathrm{CD} 8^{+} \mathrm{T}$ cell predominance within insulitis and HLA class I hyperexpression in islets has been observed exclusively in individuals with T1D [34]. $\mathrm{CD} 8^{+} \mathrm{T}$ cells are under increased scrutiny to identify key receptors and characterize their functional role in T1D development for potential use as biomarkers or therapeutic targets. Indeed, insulitic $\mathrm{CD} 8^{+} \mathrm{TCR}$ reactivities appear unique to individual islets in the limited number of recent-onset T1D organ donors examined so far; perhaps these represent local clonal expansions, with nearby islets demonstrating autoreactivity to distinct epitopes/ autoantigens [34]. Moreover, HLA-A*02-01-tetramer staining for epitopes derived from six known T1D autoantigens demonstrated glucose-6-phosphatase 2 (G6Pase 2)-reactive $\mathrm{CD} 8^{+} \mathrm{T}$ cells to be the most prevalent within lesions examined from 45 T1D donors of varying disease durations [34]. Insulitic lesions were specific for a single $\beta$-cell autoantigen in donors with recent-onset disease whereas diverse $\mathrm{T}$ cell autoreactivity was observed in the majority of donors with longstanding disease. Lack of autoreactivity to any epitope tested was noted from two long duration ( $\geq 1$ year) cases, even in the presence of insulitis [34]. Monospecificity early in disease followed by oligoclonal $\mathrm{T}$ cell expansion may be seen within human islets as T1D advances, similar to epitope spreading demonstrated in the NOD mouse [35]. Efforts to investigate this phenomenon in human tissues are limited by the inability to perform longitudinal studies of the T1D pancreata. Nevertheless, we predict that insulitis lesions in human pancreata with long- versus short-duration T1D will show evidence of similar evolution over time.

Antigen-driven expansion of autoreactive T cells occurs in T1D patients who have undergone pancreas transplant with recurrent T1D. This process is marked by sudden and severe hyperglycemia, the appearance of new islet autoantibodies [i.e., glutamic acid decarboxylase 65 (GAD65), insulinomaassociated protein-2 (IA-2), zinc transporter 8 (ZnT8)], and expansion of autoreactive $\mathrm{T}$ cells. Circulating $\mathrm{T}$ cell autoreactivity varied across transplant recipients with GAD65-specific $\mathrm{CD}^{+} \mathrm{T}$ cells identified from two patients and G6Pase 2-reactive $\mathrm{CD} 8^{+} \mathrm{T}$ cells from a third. In one patient, GAD65-reactive $\mathrm{CD}^{+}{ }^{+} \mathrm{T}$ cells were present in the peripheral blood, the transplanted pancreas, and pancreas 
draining $\mathrm{LN}$ ( $\mathrm{pLN}$ ) with persistent detection of a single TCR $\beta$-chain complementarity determining region 3 (CDR3), despite immunosuppressive treatment [36•]. A fourth transplant recipient had GAD65-specific $\mathrm{CD}^{+} \mathrm{T}$ cells exhibiting a $\mathrm{CCR}^{-}$memory phenotype within the pancreas transplant draining LN. Histologically, B cell and T cell insulitis, $\beta$-cell loss, and variable degrees of transplant rejection were seen [36•]. These observations highlight that not only is the autoreactive $\mathrm{T}$ cell repertoire pathogenic, but also the memory $\mathrm{T}$ cell response persists for many years and may display resistance to drugs capable of suppressing allograft rejection.

\section{Putatively Known Autoreactive TCRs}

\section{Analyses in Peripheral Blood}

T cell clones specific for $\beta$-cell antigens (e.g., G6Pase 2 , insulin, pre-proinsulin, IA-2, GAD65, ZnT8 [37]) have been isolated from peripheral blood of living patients with T1D but can also be detected from control subjects [18, 23•, 24, 38•, 39-42]. We and others have demonstrated high diversity of the TCR repertoire, even within the islets and pLNs of patients with T1D and autoantibody positive subjects who have elevated risk of progressing to disease [23•, 38•]. Functionally, detailed studies have revealed that peripheral blood T cells from HLA-matched T1D and control subjects produce IFN- $\gamma$ versus IL-10, respectively, in response to activation with autoantigen [43]. Two GAD-reactive TCR clones, 4.13 and R164, isolated from peripheral blood of patients with T1D were derived from shared TCR $\alpha$ and TCR $\beta$ variable (V) gene segments recognizing a common peptide target (i.e., $\mathrm{GAD}_{555-567}$ ). These clones have only minor functional differences in the amino acid sequence of the CDR3 domain but exhibit different binding avidities [44]. In vivo studies of humanized TCR-transgenic mice expressing the lower-avidity 4.13 or high-avidity R164 clone revealed differences in thymic selection and peripheral T cell skewing. 4.13 TCR-transgenic mice exhibited a more tolerogenic repertoire including IL-10 producing T cells whereas R164 TCRtransgenic mice were observed to exclusively contain IFN- $\gamma$ positive T cells [45]. To further examine the functional implications of TCR avidity in vitro, we used lentiviral transduction of primary human $\mathrm{T}$ cells to engineer GAD 4.13 and GAD R164 TCR avatars. Compared to 4.13 Tregs, high-avidity R164 Tregs exhibited greater suppressive capacity over antigen-specific responder T cells activated with $\mathrm{GAD}_{555-567}$ peptide or bystander $\mathrm{CD}^{+} \mathrm{T}$ cells recognizing a MART-1 peptide (Yeh et al., in press). These studies suggest autoreactive TCR avidity likely influences the functions of both Treg and effector T cell (Teff) populations in T1D pathogenesis. However, these studies cannot directly infer diabetogenicity and have led to investigations of T cells isolated from islet tissues of deceased organ donors with T1D.

\section{Islet Studies}

In one of the first studies of T cells isolated from a human T1D pancreas, clones from five TCR $\beta$ V-gene families $(\mathrm{V} \beta 1$, $\mathrm{V} \beta 7, \mathrm{~V} \beta 11, \mathrm{~V} \beta 17, \mathrm{~V} \beta 22)$ were found to be expanded. One of these clonal expansions, $\mathrm{V} \beta 22$, was also expanded in spleen and peripheral blood; however, autoantigen or epitope reactivities were not determined for the expanded clones [46]. We recently reported an extensive analysis of the adaptive repertoire from $\mathrm{pLN}$, spleen, $\mathrm{PBMC}$, and inguinal or mesenteric LN of 18 T1D and nine control organ donors [38•]. These efforts also demonstrated limited clonal overlap between circulation and the target organ (Fig. 1a) and support the notion that studies of peripheral blood T cells alone are likely insufficient to fully characterize the T1D autoimmune repertoire, highlighting the need for studies of intra-pancreatic T cells in T1D.

As noted above, insulitis is heterogeneous throughout the human T1D pancreas, most often affecting residual insulincontaining islets, and the ability to expand live $\mathrm{T}$ cells from isolated human islets containing insulitis represents a remarkable achievement. Indeed, Pathiraja et al. characterized 53 intra-islet $\mathrm{CD}^{+} \mathrm{T}$ cell clones and reported that 14/53 reacted with proinsulin [167]. CDR3 sequences were not conserved across the 14 proinsulin-reactive intra-islet $\mathrm{T}$ cell clones suggesting that they did not originate from a common parent clone. Similarly, Michels et al. characterized three proinsulin-reactive T cell clones (i.e., 20D11, 6H9, and 8E3) isolated from human T1D islets; 20D11 and EH9 are the first human intra-pancreatic isolates specific for the insulin B:9-23 peptide [168••]. In a recent report by Babon et al., GAD-, proinsulin-, IA-2-, and chromogranin A-reactive $\mathrm{CD}^{+}{ }^{+} \mathrm{T}$ cell clones were isolated from human islets from organ donors with T1D [169••]. $\mathrm{CD}^{+} \mathrm{T}$ cells specific for insulin, IA-2, and G6Pase 2 peptides were also detected. Functionally, antigen-stimulated cytokine secretion varied across clones but, overall, it was pro-inflammatory with a Th1 bias [169••]. Further, our recent study of intra-islet T cells from one T1D donor revealed a TCR $\beta$ CDR3 corresponding to the previously identified GAD-reactive clone 4.13; no other known autoreactive clones were identified from the islet sample [38•]. GAD4.13 was identified in LN or spleen samples from six additional T1D donors. These reports highlight the apparent heterogeneity of $\mathrm{T} 1 \mathrm{D}$ with regard to $\mathrm{T}$ cell antigen reactivity and $\mathrm{T}$ cell function/phenotype. These studies also emphasize the need for large datasets to illuminate molecular patterns likely governed by HLA and minor T1D risk alleles (e.g., INS/IGF2) that might influence clonal frequency throughout the natural history of disease (Fig. 2). 
a Tissue Restricted vs. Circulating Clones
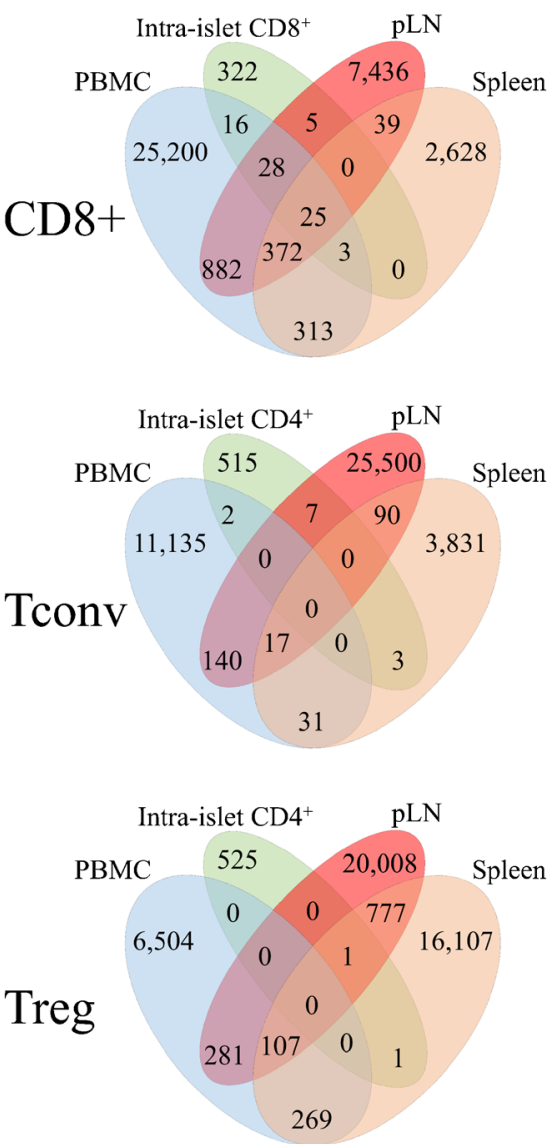

Fig. 1 Potential applications for next-generation sequencing (NGS) of the $\mathrm{T}$ cell receptor (TCR) repertoire in type 1 diabetes (T1D) research. a For the $\mathrm{CD}^{+}{ }^{+} \mathrm{T}$ cell, $\mathrm{CD} 4^{+}$conventional $\mathrm{T}$ cell (Tconv), and regulatory $\mathrm{T}$ cell (Treg) subsets, the number of TCR $\beta$ complementarity determining region 3 (CDR3) amino acid (AA) sequences shared across peripheral blood mononuclear cells (PBMC, blue), intra-islet (green), pancreatic draining lymph node (pLN, red), and spleen (orange) samples from a single donor (Reprinted with permission from: Seay HR, et al. JCI Insight. 2016;1(20):e88242) [38•]. b Circos plot depicting TRBV and TRBJ gene families detected from a single PBMC sample. Colored ribbons represent each gene family with frequency corresponding to ribbon width. V-J combinations are indicated by ribbons connecting across the circle. c Six thousand three hundred and twenty-one clonotypes of known reactivity are shown here for $>20$ diseases with the number of known clonotypes indicated in parentheses for nine of the most abundant: T1D $N=1655$ (red), human immunodeficiency virus (HIV) $N=640$ (beige), Influenza $N=522$ (purple), melanoma $N=548$ (teal), Epstein-Barr virus (EBV) $N=492$ (light purple), cytomegalovirus (CMV) $N=481$ (bright blue), rheumatoid arthritis (RA) $N=272$ (gray blue), multiple sclerosis (MS) $N=118$ (orange), and systemic lupus erythematosus (SLE) $N=88$ (light green) [23•, 46-165]. d CMVassociated TCR $\beta$ sequences were identified from CMV seropositive (orange) and CMV seronegative (blue) subjects (left). Computer models were trained using CMV-associated TCR $\beta$ and CMV seropositivity status data (cohort 1 , dashed lines). Models were validated using a separate cohort of individuals (cohort 2, solid line). Receiver operating characteristic (ROC) curve analyses indicate that NGS can identify CMV serostatus with sensitivity $=0.90$ and specificity $=0.89$; area under $\mathrm{ROC}$ $($ AUROC $)=0.93$ for cross-validation of cohort 1 and AUROC $=0.94$ for cohort 2 (Reprinted by permission from Macmillan Publishers Ltd.: Emerson RO, et al. Nat Genet. 2017;49(5):659-65) [166••]
T Cells Recognizing Neo-epitopes, Defective Ribosomal Products, and Hybrid Insulin Peptides

Growing evidence supports a role for epitopes derived from defective ribosomal products (DRiPs) and hybrid insulin peptides (HIPs) as potentially initiating autoantigens in T1D (Fig. 2). DRiPs result from dysfunctional or erroneous translation of pre-proinsulin transcripts [173••]. For instance, translation of INS mRNA from an alternative open reading frame can generate novel, seemingly aberrant peptides. In a recent report by Kracht et al., $\mathrm{CD} 8^{+} \mathrm{T}$ cells specific for an insulin DRiP peptide were isolated from peripheral blood of patients with T1D and were demonstrated to specifically destroy human islet cells in vitro [173••]. Similarly, HIPs are derived from the post-translational fusion of proinsulin peptides with other $\beta$-cell proteins within the secretory granule $[174 \bullet \bullet]$. HIPreactive $\mathrm{T}$ cells have been isolated from the pancreata of human organ donors with T1D, and perhaps not surprisingly, the HIP-reactive clones (A2.11 and A3.10) exhibited HLA-DQ8 restriction $[174 \bullet \bullet]$. T cells recognizing modified insulin epitopes are likely not subjected to regulation by central tolerance mechanisms, and there is evidence suggesting DRiP and HIPreactive $\mathrm{T}$ cells may be present in both control and T1D subjects $[173 \bullet \bullet$. However, high-risk HLA haplotypes may preferentially present DRiP and HIP neo-epitopes generated within the $\beta$-cell, supporting a diabetogenic role. Hence, $T$ cells recognizing DRiPs and HIPs likely represent an important class of potential TCR biomarkers, particularly within the context of certain HLA haplotypes, and may represent candidate targets for novel $\mathrm{T}$ cell-directed therapies.

\section{Technologies for Analyzing TCR Sequences}

Being a budding field, high-throughput immunosequencing (REP-seq) does not have a well-defined or standardized methodology for data acquisition and analysis. The reasons for this variability are many but relate to the use of different sample input tissues, sequencing platforms, and data analysis pipelines. The choice of analysis platform is highly dependent upon the needs for sample depth and resolution, along with practical considerations of cost. A number of technologies have been utilized for the acquisition and analysis of TCR sequences, varying from single investigator concepts to turnkey commercial processing pipelines. Below, we review some of the previously utilized approaches and describe emerging technologies for immunosequencing applications (Table 1).

\section{Next-Generation Immunosequencing Approaches}

Next-generation sequencing (NGS) of the TCR $\beta$ and B cell receptor (BCR) IgH chain has enabled investigation of the adaptive immune repertoire from small blood or tissue samples. 
b TRBV and TRBJ Gene Usage and Pairing

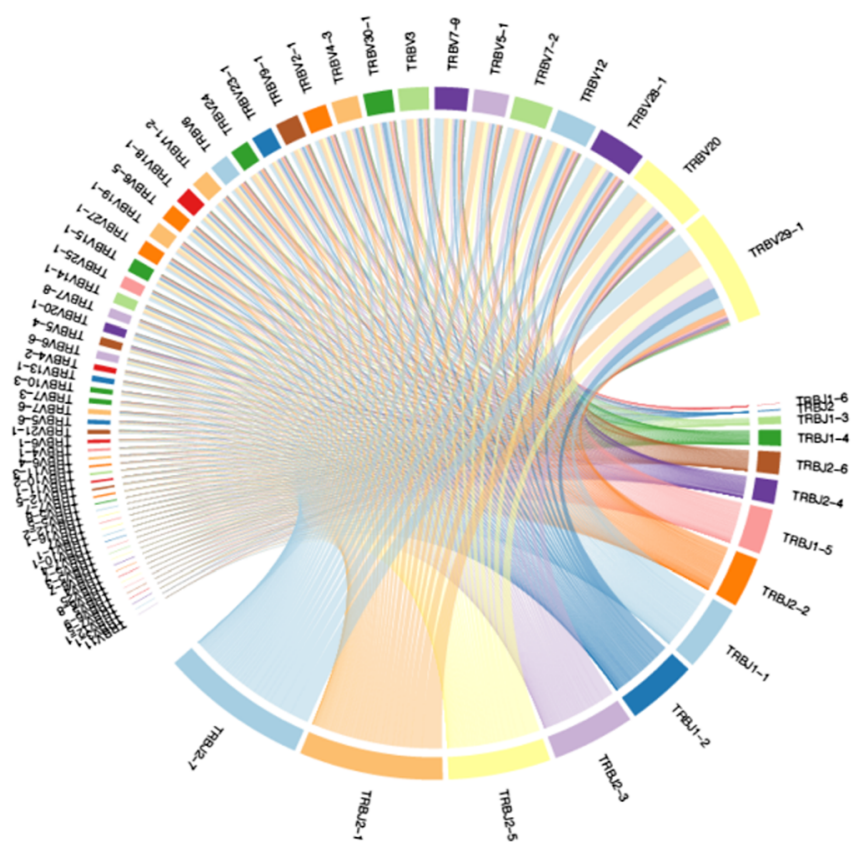

C

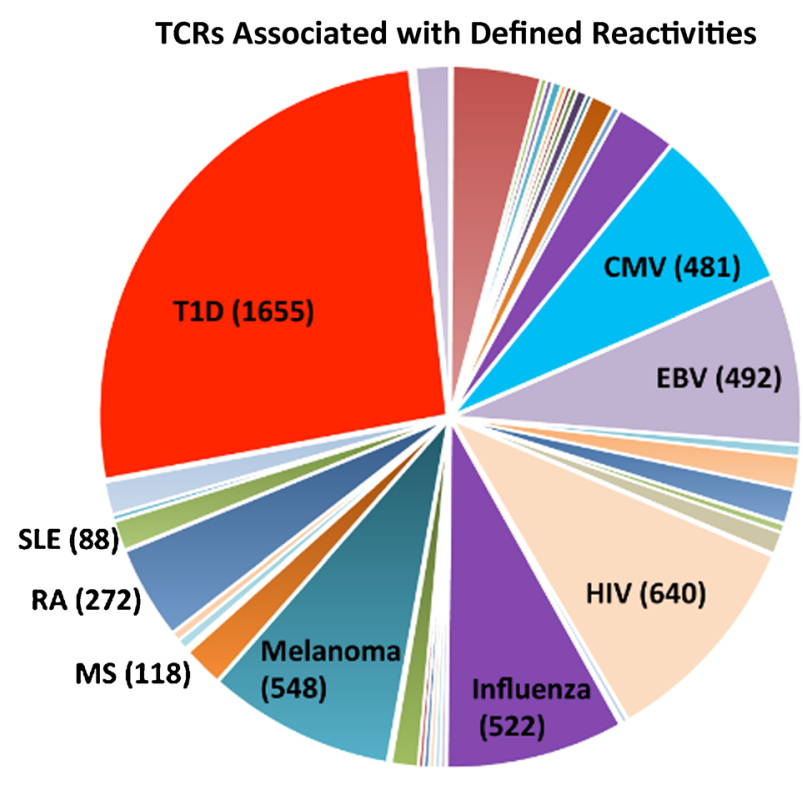

d Disease vs. Control or Progressor vs. Non-progressor

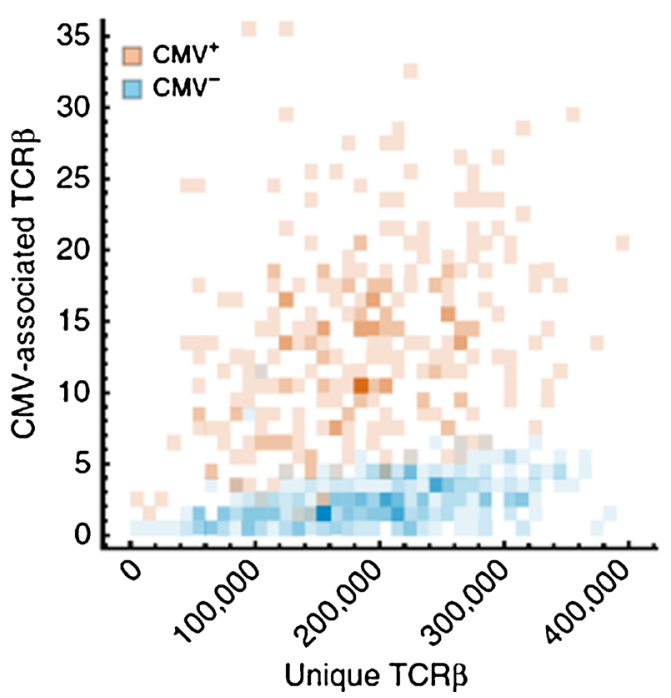

Fig. 1 (continued)

DNA/RNA from fluorescence-activated cell sorter-isolated immune cell subsets can be used to generate recombined receptor sequences using an Illumina sequencing platform $[38 \bullet$, 175••, $212,213]$. These technologies have quickly facilitated the generation of massive datasets (generally $5 \times 10^{4}-1 \times 10^{6}$ sequence reads per sample) presented in proprietary and public databases (e.g., https://clients.adaptivebiotech.com/immuneaccess and for T1D sequences, http://clonesearch.jdrfnpod.org/). In turn, there is a need to develop new methods to parse, analyze, and graphically depict the extensive information [214]. Indeed, it is now possible to rapidly evaluate repertoire dynamics that

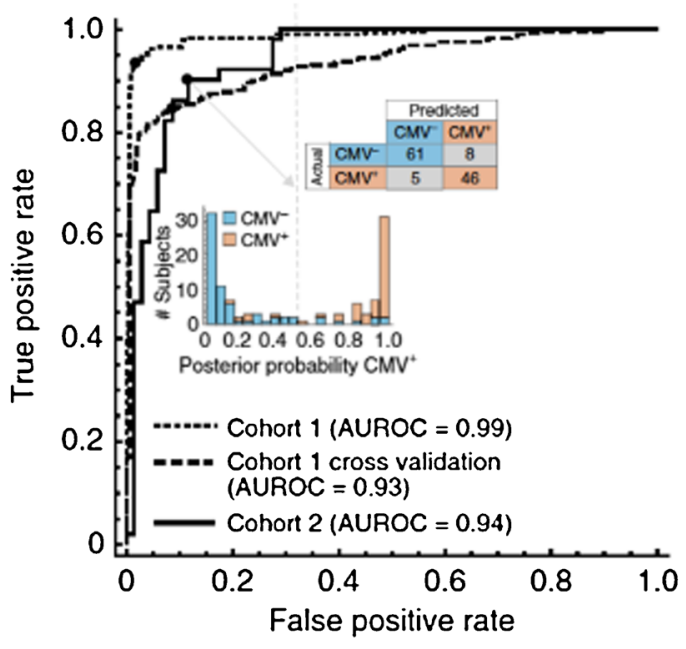

include measures such as overlap across samples (Fig. 1a) and experimental groups, TCR sharing among multiple T cell subsets, comparisons of clonality and diversity, V(D)J gene usage (Fig. 1b), and public TCR sequences (Fig. 1c). Moreover, algorithms to identify individual clones by nucleotide and/or amino acid sequences, bioinformatics approaches are emerging to identify common peptide-binding motifs to facilitate the identification of classes of TCRs capable of binding shared peptides/ epitopes [43].

High-depth NGS assays are limited by the current inability to simultaneously detect and pair TCR $\alpha$ and TCR $\beta$ 
Stages of T1D Development
Presymptomatic T1D

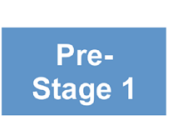

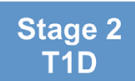

T1D
Symptomatic T1D

\begin{tabular}{c|c}
\hline Stage 3 & Stage 4 \\
T1D & T1D
\end{tabular}

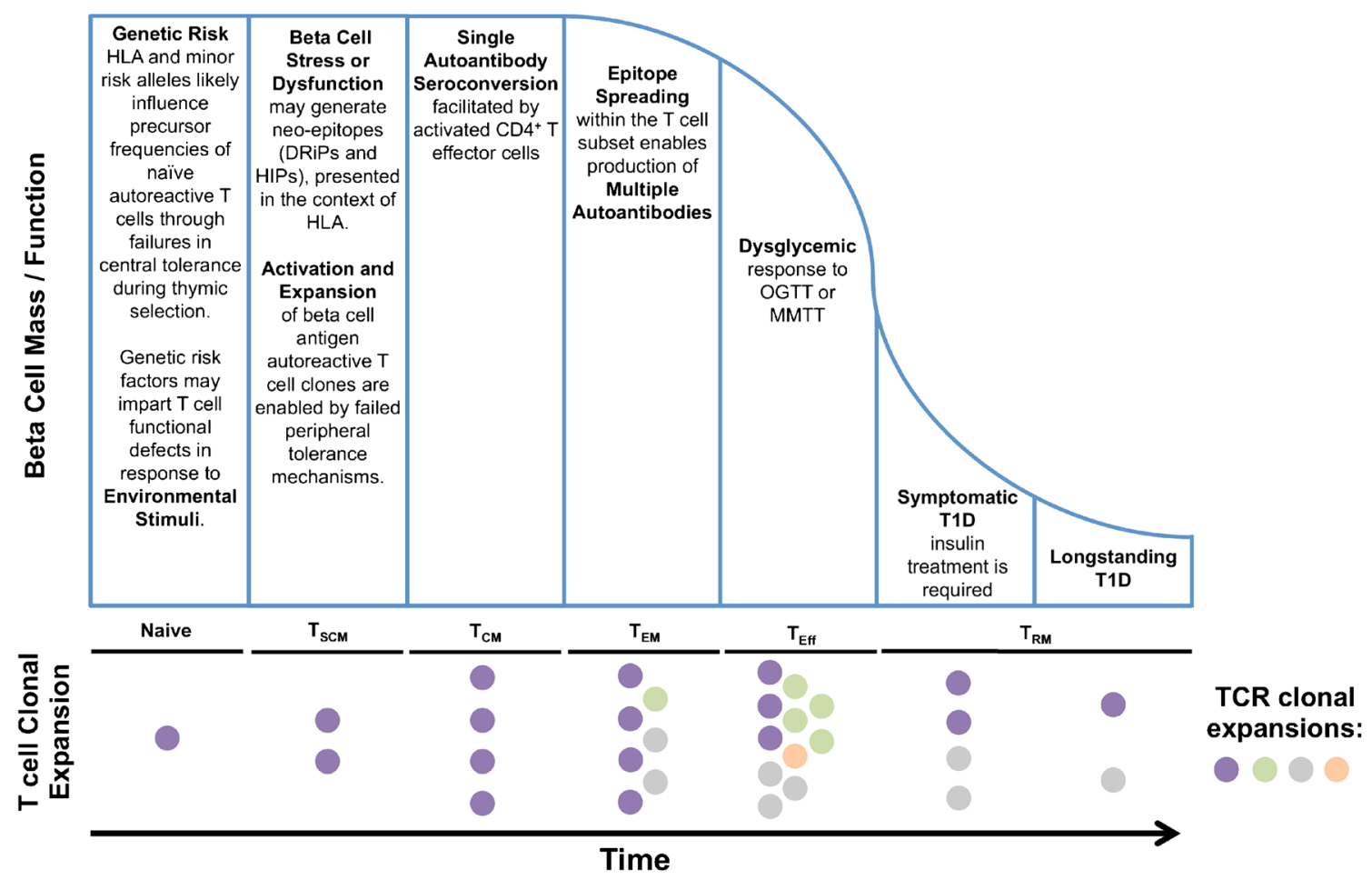

Fig. 2 Hypothesized timeline of T cell clonal expansion as it relates to the development of autoantibodies, development of dysglycemia, and loss of $\beta$-cell mass and/or function in the natural history of type 1 diabetes (T1D). Staging of T1D is modeled after the 2015 consensus report [170 $]$ and modified from the Eisenbarth model of T1D [171, 172] with pre-disposing factors as well as key immunologic and metabolic events noted over the course of the disease. The T cell expansion diagram reflects development of a naïve $\mathrm{T}$ cell clone into stem cell memory $\mathrm{T}$ cell $\left(\mathrm{T}_{\mathrm{SCM}}\right)$, central memory $\mathrm{T}$ cell $(\mathrm{Tcm})$, effector memory $\mathrm{T}$ cell $\left(\mathrm{T}_{\mathrm{EM}}\right)$, effector $\mathrm{T}$ cell $\left(\mathrm{T}_{\mathrm{Eff}}\right)$, and tissue resident memory $\mathrm{T}$ cell $\left(\mathrm{T}_{\mathrm{RM}}\right)$ subsets based on the model presented by Farber et al. [21], with colors (i.e., purple, green, gray, orange) representing T cell receptor (TCR) clonal expansions sequences, yet these high-throughput discovery efforts provide a powerful clinical screening tool that retains the sensitivity to detect rare clones. Intermediate-depth applications such as RNA-seq or primer targeted sequencing yield less coverage and fewer sequence reads, but both TCR $\alpha$ - and $\beta$ chain sequencing can be obtained from laser-captured tissue microdissections or sorted lymphocyte subsets. Isolated RNA can be reverse transcribed to cDNA and amplified for transcriptome profiling to identify TCRs derived from alternate open reading frame transcripts and specific allelic expression [215]. Though moderate depth NGS does not allow for complete reconstruction of the TCR or identify exact epitope reactivity, these techniques can be used to characterize clonality, diversity, and gene segment usage for both the TRA and TRB genes. Adaptive pairSEQ allows for pairing of specific TCR $\alpha$ and TCR $\beta$ sequences by leveraging fractioning and probability based on relative abundance. However, there is a large input requirement and only highly prevalent sequences can be accurately paired.

Single-cell NGS tools involving directed-sequencing provide the ability to reconstruct the complete TCR with $\alpha$ - and $\beta$-chain pairing, which is required to confirm precise antigen reactivity and perform functional studies in vitro. Specifically, efforts that combine directed TCR $\alpha$ - and $\beta$-chain pairing with the additional analysis of lineage specific transcription factors and effector molecules not only provide the greatest opportunity for biomarker discovery but also have a bias toward detection of the most frequent clones [216]. Indeed, single-cell transcriptional profiling technologies offer high specificity and depth of information but low depth of coverage at considerable single-cell cost [175••]. New platforms and approaches are addressing this limitation, with droplet-based mRNA-seq or $\alpha$ - and $\beta$-chain sequence pairing potentially facilitating analysis of single cells with improved throughput capacity [43, 217••].

\section{TCRs as Biomarkers}

\section{Limitations of Current T Cell Biomarkers}

Marrero et al. identified islet antigen-reactive TRBV13-2 (Vß8.2) public clones from the pLN of NOD mice. 


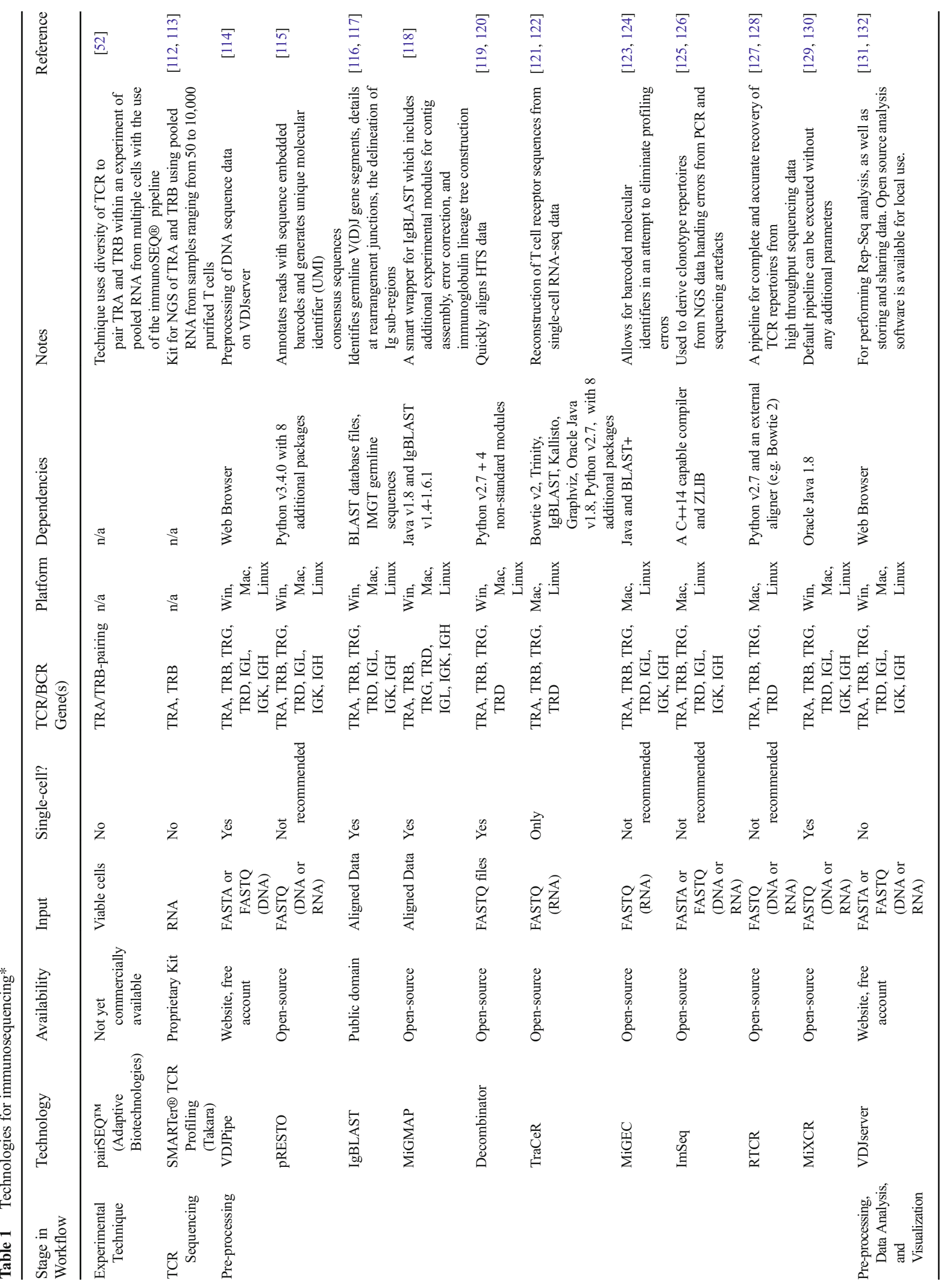




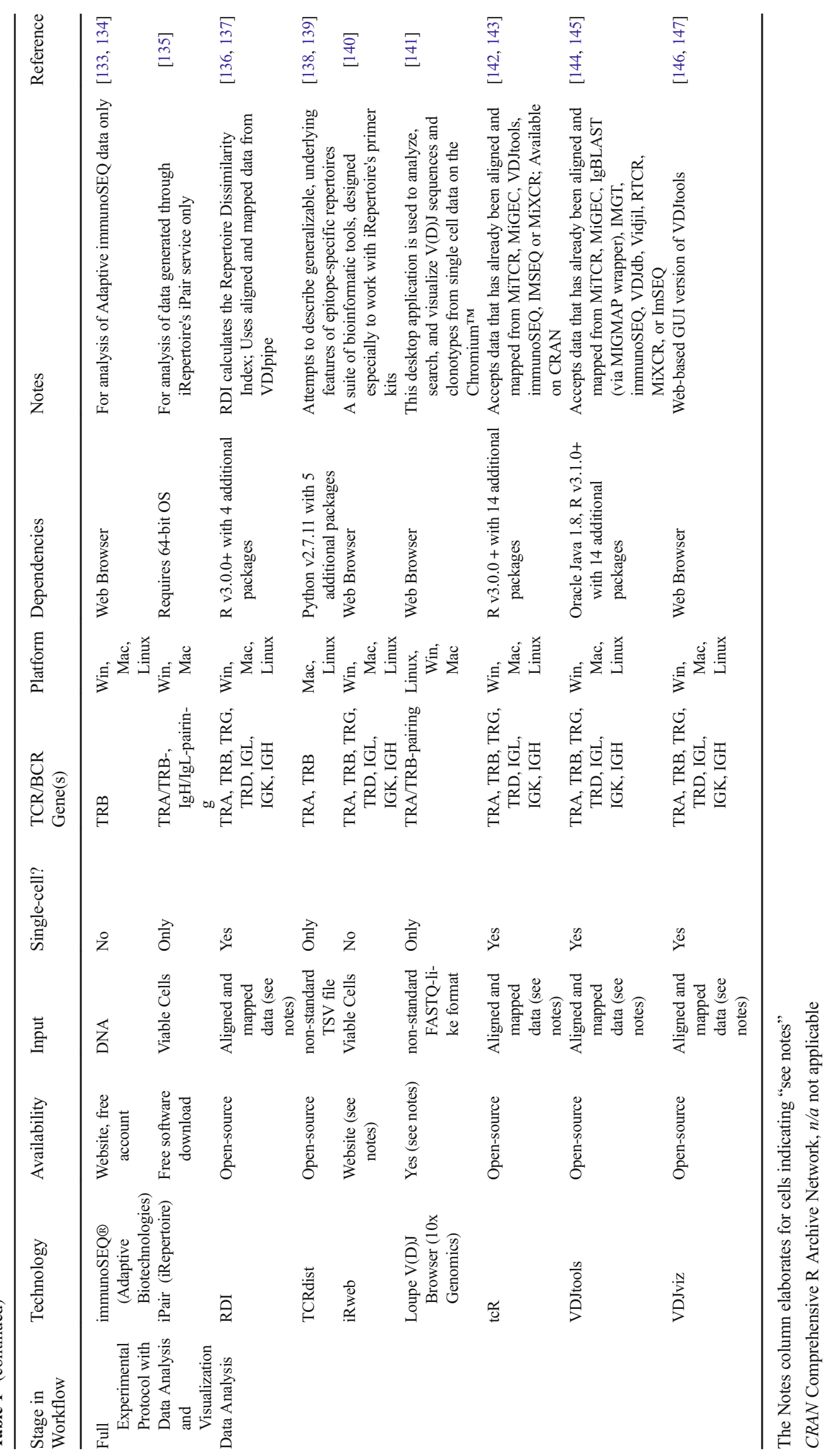


Importantly, a tolerogenic vaccine composed of an immunodominant peptide that binds the TCR V $\beta 8.2$ chain prevented T1D in NOD mice [47] supporting the notion that public TCRs may serve as biomarkers and potential therapeutic targets. Currently, autoantibodies represent the best available biomarker to predict human T1D onset. At least $85 \%$ of children with multiple $\beta$-cell-reactive autoantibodies will progress to symptomatic disease within 15 years - with a lifetime risk approaching $100 \%[170 \cdot, 218]$. Hence, there is a need to identify autoreactive $\mathrm{T}$ cell biomarkers in the pre-diabetic period, ideally prior to the loss of endogenous $\beta$-cell mass/function (Fig. 2). When combined with genetic risk markers and/or seropositivity for islet autoantibodies, $\mathrm{T}$ cell biomarker(s) may represent an early predictive index of disease; the goal, to employ these early clonal sequences as biomarkers of T1D progression, identify suitable candidates for therapy, develop novel $\mathrm{T}$ cell-targeted therapies, and monitor therapeutic responses.

Prior studies to assess cellular immunity and identify $\mathrm{T}$ cell biomarkers of T1D relied on immunoblot, T cell proliferation, ELISpot, and multimer staining with flow cytometry assays. These approaches can discriminate patients with T1D from healthy controls, though sensitivity and specificity are lower than assays detecting autoantibodies [15]. However, immunoblot and $\mathrm{T}$ cell proliferation assays often require freshly isolated cells, which limit their use in interventional trial settings [219]. Conversely, ELISpot and MHC multimer-based screening methods are able to precisely identify the target antigen and epitope as well as T cell phenotype, but sample requirements and HLA restriction hinder multi-center utility. Through TCR and transcriptional profiling, investigators now have the capacity to identify $\mathrm{T}$ cell clones, phenotype, and the specific epitope reactivities of $\mathrm{T}$ cells regardless of HLA haplotypes.

\section{Lessons From Studies of Infectious Disease and Cancer}

As a well-studied and penetrant pathogen in the US general population, cytomegalovirus (CMV) provided a useful model for studies of TCR $\beta$-chain sequencing [166••]. Through high-throughput analyses coupled with machine learning, investigators were able to identify CMV-reactive TCRs and accurately infer CMV seropositivity status from the TCR repertoire with area under the receiver operating characteristic curve $($ AUROC $)=0.94$ (Fig. 1d). Interestingly, only 164 of the 488 (34\%) CMV-reactive TCR $\beta$ identified were significantly associated with CMV seropositivity [166••]. Perhaps not surprisingly, the authors noted that public CMVassociated TCR $\beta$ sequences were only identified from HLAmatched cohorts, supporting the notion that TCR biomarkers are HLA restricted. Altogether, these findings suggest that given a sufficiently large cohort, it may be possible to build computer algorithms to determine an individual's likelihood of progression to T1D based upon TCR repertoire analysis, for specific HLA types.
Similar efforts in the field of cancer research have led to advancements in treatment and monitoring of disease. Notably, immune receptor deep sequencing can now be used to characterize acute lymphoblastic leukemia as monoclonal or polyclonal, identify the malignant $\mathrm{T}$ cell or $\mathrm{B}$ cell developmental stage, monitor disease progression, and track therapeutic response [220 ]. NGS is also of great value for monitoring rare $\mathrm{T}$ cell lymphomas, which are difficult to detect by traditional methods and consequently, are associated with poor prognosis [221]. When sequencing is performed at baseline prior to treatment, the TCR or BCR repertoire can be followed throughout therapy, and minimal residual disease (MRD), which is considered the most reliable means to predict patient outcome and potential for relapse, can be evaluated with greater sensitivity via immunosequencing (i.e., 1 in $10^{6}$ cells) compared to previous standard methodologies (i.e., flow cytometry or allele-specific oligonucleotide PCR (ASO-PCR)) [220• 222, 223]. These concepts have the potential to be translated to T1D research, wherein autoreactive clones could be monitored to evaluate therapeutic response following immunomodulatory therapies, with the goal to detect persistent autoreactive memory lymphocytes in circulation and potentially track relapsing and remitting phases characteristic of many autoimmune diseases [224].

\section{Novel Methodology to Improve Detection}

When considering how to apply TCR biomarkers in T1D clinical trials, tissue restriction of the $\mathrm{T}$ cell repertoire represents a critical limitation [38•]. Indeed, our recent study suggested that $\mathrm{CD}^{+} \mathrm{T}$ cell clones are highly tissue restricted while $\mathrm{CD}^{+} \mathrm{T}$ cells clones may be present in multiple tissues and in circulation (Fig. 1a) [38•]. Because T cells targeting $\beta$ cell antigens are most abundant within the $\mathrm{pLN}$ or the pancreas itself [38•], strategies are needed to improve recovery of autoreactive clones from accessible tissues (i.e., peripheral blood). To address this, Thelin et al. utilized subcutaneous scaffolds bearing $\beta$-cell lysates to draw an enriched population of autoreactive T cells from the circulation of NOD mice [225]. While further investigation is clearly needed, a safe analogous methodology could be utilized to improve the recovery of autoreactive $\mathrm{T}$ cell clones following a local challenge. Beyond this, longitudinal studies are needed to identify the initiating autoreactive TCRs, address whether there is evidence of epitope spreading at the clonal level, and to characterize antigenic spreading throughout the pre-T1D period (Fig. 2).

\section{TCR Sequencing in T1D}

Efforts to identify public TCR using NGS are still in the early stages in the field of T1D research. Thus far, the greatest challenge stems from high repertoire diversity 
and low levels of clonal overlap, when comparing across subjects and tissues. In our study of 18 T1D and nine control subjects, deep sequencing of TCRs from $\mathrm{T}$ cell subsets (isolated from pLN, spleen, PBMC, and inguinal or mesenteric LN) showed that limited Treg or conventional $\mathrm{CD}^{+} \mathrm{T}$ cell (Tconv) repertoire overlap exists across tissues and in the circulation within a given individual (i.e., 3-4\% overlap between $\mathrm{pLN}$ and PBMC for T1D donors) [38•]. Comparatively, within the $\mathrm{CD} 8^{+} \mathrm{T}$ cell subset, approximately $20 \%$ of clones were shared across pLN and PBMC [38•]. Further, for one donor, we were able to sequence the intra-islet $\mathrm{T}$ cell isolate. We found only seven $\mathrm{CD}^{+}{ }^{+} \mathrm{TCR}$ clones conserved across islet and $\mathrm{pLN}$ samples. However, $58 \mathrm{CD} 8^{+}$TCRs were detected from both $\mathrm{pLN}$ and islet tissues. Within this cohort, seven HLA-A*02 matched T1D donors were examined for public TCRs within the pLN and 14 unique CDR3 sequences were common across the $\mathrm{CD} 8^{+}$population from each of the seven donors [38•]. Hence, we expect that $\mathrm{CD} 8^{+} \mathrm{T}$ cells may serve as a more reliable $\mathrm{T}$ cell biomarker in T1D.

The sheer number of unique sequences present has raised a new challenge as investigators search for public autoreactive clone(s), a so-called needle in a haystack. In fact, contrary to our original hypothesis, global TCR repertoire analysis could not be used to discriminate T1D from control donors by broad TRB gene usage. However, when we queried TCR NGS data for known autoreactive $\mathrm{T}$ cell clonotypes, we identified 59 unique CDR3 $\beta$-chain amino acid sequences, the majority of which were more prevalent in T1D donor tissues versus control or type 2 diabetes samples [38•]. Moreover, we reported the CDR3 $\beta$-chain sequence of the GAD-reactive TCR clone (4.13) to be highly enriched for seven T1D donors and one autoantibody negative control subject with T1D permissive HLA, perhaps representing a key driver of T1D pathogenesis in these subjects. However, studies of multiple T cell subsets, autoantibody positive organ donors, and longitudinal studies of living subjects are needed to further characterize the pathogenic or protective role of this clone.

As noted above, Han et al. observed common sequence motifs, where nucleic acid alterations within the $\mathrm{V}(\mathrm{D}) \mathrm{J}$ junction resulted in TCRs with variability at the amino acid level but similar tumor antigen reactivities [43]. This notion of shared motifs must be explored further in T1D where a particular public clone seems unlikely to be present in all or even the majority of patients, but pathogenic $\mathrm{T}$ cells with common antigen reactivities are expected. Together, these observations point toward a need for machine learning algorithms to determine conserved autoreactive TCR repertoires concurrent with established biomarkers (i.e., autoantibodies, genetic risk alleles), early in the disease process when intervention is most likely to impact disease course.

\section{TCRs as Therapeutics}

\section{Clinical Response to $\mathrm{T}$ Cell Targeting Therapeutics}

For nearly 50 years, immunomodulatory agents, including those aimed at $\mathrm{T}$ cell blockade, have been prescribed to prevent rejection and graft versus host disease in solid organ and bone marrow transplant recipients [226-230]. Immunosuppressants targeting global or precise $\mathrm{T}$ cell frequency and function have since been applied for the treatment of autoimmune diseases, such as multiple sclerosis (MS) and rheumatoid arthritis (reviewed in [231, 232]). T cell-targeted therapies have been tested in multiple T1D clinical trials aiming to interdict in the destruction of $\beta$-cells and preserve C-peptide production [233-249]. Though no T cell-targeted therapy has achieved long-term remission with clinical equipoise, evidence of temporary or partial efficacy in subsets of responder subjects has been observed following treatment with antithymocyte globulin (ATG) alone or in combination with granulocyte colony stimulating factor (G-CSF), teplizumab, alefacept, or abatacept [236, 242, 243, 246, 247, 249, 250].

ATG, cyclophosphamide, and G-CSF were key components of autologous non-myeloablative hematopoietic stem cell transplants, which restored insulin independence in patients with T1D but conferred high risk of morbidity (e.g., severe neutropenia requiring extended hospitalization, gonadal dysfunction, alopecia) [251, 252]. ATG induces T cell apoptosis and complement-dependent lysis, B cell apoptosis, modulation of antigen presenting cell surface molecules and induction of Tregs [253] while G-CSF stimulates hematopoietic mobilization [254]. Due to the high-risk nature of this approach, several groups have attempted to deconstruct this combination approach in hopes of designing lower risk therapies that maintain efficacy. Specifically, Haller et al. recently demonstrated that low-dose ATG plus G-CSF preserved Cpeptide for 12 months in subjects with established T1D (4 24 months post-diagnosis), with responders characterized by older age at disease onset [246]. Combination treatment with low dose ATG and G-CSF induced significant and sustained immunomodulation including elevated Tregs, reduced $\mathrm{CD}^{+}$ and increased $\mathrm{CD} 8^{+} \mathrm{T}$ cell frequency, increased $\mathrm{CD} 16^{+} \mathrm{CD} 56^{\mathrm{hi}} \mathrm{NK}$ cell frequency, and increased frequency of $\mathrm{CD}^{+} \mathrm{PD}-1^{+} \mathrm{T}_{\mathrm{CM}}$ [247]. Accordingly, NGS studies in our lab are ongoing to evaluate precise effects of therapy on the TCR repertoire. Earlier intervention is expected to provide improved efficacy, and a study of ATG plus G-CSF combination therapy in new-onset T1D subjects will reach the primary endpoint in late 2017 (NCT02215200).

Development of humanized monoclonal antibodies and immunomodulatory fusion proteins have led to similar trials of T cell-directed therapies - namely, anti-CD3 (teplizumab), LFA-3/Fc fusion protein (alefacept), and CTLA-4/Fc fusion 
protein (abatacept). While space limitations preclude an extensive review of these studies, it is important to note that each of these agents has demonstrated signal indicating capacity to preserve C-peptide through $\mathrm{T}$ cell modulation. That said, it is not yet known how these $\mathrm{T}$ cell modulating agents (i.e., anti$\mathrm{CD} 3$, alefacept, abatacept, or ATG \pm G-CSF) impact the autoreactive $\mathrm{T}$ cell repertoire, and detailed investigations within prevention and reversal trials are warranted. We speculate that early intervention, prior to epitope spreading, may provide the best opportunity to deplete immunodominant autoreactive clonotypes using monoclonal antibodies or similar agents (Fig. 2). Moreover, selection of the optimal biologic for tailored immune therapy may depend upon subject age, T1D disease stage, or additional biomarkers, which have yet to be defined. Identification of autoreactive $\mathrm{T}$ cell clone(s) through NGS could provide candidate targets for monoclonal therapy, ideally, before autoantibody development occurs. These notions support ongoing investigation to identify key pathogenic clones as targets for $\mathrm{T}$ cell-directed immunotherapy.

\section{The Engineered TCR and CAR-T Experience}

Autologous chimeric antigen receptor (CAR) T cells, engineered to express a tumor antigen-specific immunoglobulin variable region (single-chain variable fragment $(\mathrm{scFv})$ ) fused to TCR and costimulatory signaling domains, represent a promising therapeutic strategy for the treatment of solid tumors, B cell leukemia, and lymphoma [255-258]. A particular benefit in settings of cancer lies in the ability to deplete malignant cells without the requirement for antigen presentation via HLA; likewise, lack of HLA restriction could enable non-autologous T cell sources. Indeed, CAR-Tregs could be generated for application in T1D by expressing a $\beta$-cell antigen-reactive immunoglobulin $\mathrm{scFv}$ providing tissue-targeted activation and eliciting bystander suppression. However, limitations exist related to the requirement for surface expression of the target antigen(s) on islets or $\beta$-cells. Alternatively, TCR gene transfer facilitates targeted Treg therapies that recognize intra-cellular $\beta$-cell antigens presented by HLA following native antigen uptake and presentation via antigen presenting cells. TCR gene transfer can be accomplished via mRNA electroporation for transient expression $[259,260]$ or lentiviral transduction for stable TCR expression [261]. The former approach limits risk by bypassing the need for vector integration, but there may be a requirement for repeat dosing due to transient expression. Whereas in settings of T1D, longer-lived TCR "avatars" generated through lentiviral transduction may induce long-term bystander suppression and, potentially, lead to infectious tolerance to multiple autoantigens ([262] and Yeh et al., in press).

Through detailed studies using experimental autoimmune encephalomyelitis (EAE) murine models of MS, investigators have elucidated the timeline for epitope spreading throughout disease pathogenesis, indicating the optimal time points to initiate tolerogenic cell therapy [263-265]. Longitudinal investigations of epitope spreading in human T1D patients are needed and may be best accomplished through TCR repertoire profiling of characterized receptors. Such efforts could be used to outline tailored therapies involving engineered Treg avatars specific for identified autoantigen(s) (e.g., insulin, GAD, IA-2, HIPs, or insulin DRiP peptides, described above). Given that the argument for equipoise is undoubtedly different in settings of T1D versus hematologic malignancy, there is a need to validate Treg avatar lineage stability and introduce additional safety mechanisms, such as suicide genes [266]. With these notions in mind, a more complete understanding of the TCR repertoire may identify public Treg TCRs and/or antigen-reactivities that are particularly poised to induce tolerance in T1D.

\section{Moving Forward}

The emergence of high-throughput immunosequencing and improved access to pathogenic lymphocytes within the target organ and draining LN have enabled searching for T cell biomarkers of T1D. T cell repertoire characterization of human pancreas samples within the nPOD bioresource bank will serve as a training set for moving TCR biomarkers into the clinical space. Deep sequencing of TCRs is expected to provide the field with sensitive tools to predict disease and monitor therapeutic responses. While the search for T1D-initiating TCRs as biomarkers may not be successful (i.e., every patient's path to autoimmunity may be unique), knowledge of immunosequences/motifs could nonetheless aid in tracking immune responses within an individual and could potentially be used to generate antigen-specific Tregs for adoptive cell therapy. TCR-specific treatments may ultimately yield durable therapeutic benefit beyond the transient effects seen with current, non-specific T cell-directed therapies, alone or in combination with tolerance induction strategies. Beyond this, the capacity to monitor and detect expansions of rare but longlived immune memory presents the potential to monitor patients over time and pre-emptively redose and block autoimmune recurrence following restorative therapies.

Limited access to the pancreas in living subjects will likely represent a key challenge as we attempt to detect from PBMC the autoreactive clones originally identified from deceased organ donor tissues (i.e., pancreas, spleen, LN) [38•]. Longitudinal studies including birth cohort samples are needed to determine key pathogenic $\mathrm{T}$ cell clones or autoreactive motifs present in the earliest disease stages, potentially prior to insulitis or even autoantibody development. We expect that the vast collection of data and knowledge stemming from immunosequencing efforts will markedly improve our 
understanding of the immunopathogenesis of T1D and bring us closer to our ultimate goals of preventing and reversing T1D.

Acknowledgements The authors would like to thank Yanina Yegorova for her technical contribution toward generating the figures.

Author Contributions LMJ, AP, HRS, and MJH wrote the manuscript; TMB conceived of and edited the manuscript.

Funding Information I]NIH (P01 AI42288, R01 DK106191), JDRF (Career Development Award 2-2012-280), Leona M. and Harry B. Helmsley Charitable Trust, George S. Eisenbarth Award for Team Science, and the McJunkin Family Charitable Foundation, Inc.

\section{Compliance with Ethical Standards}

Conflict of Interest Laura M. Jacobsen, Amanda Posgai, Howard R. Seay, Michael J. Haller, and Todd M. Brusko declare that no conflicts of interest exist relevant to the contents of this work.

Human and Animal Rights and Informed Consent All reported studies/experiments with human or animal subjects performed by the authors have been previously published and complied with all applicable ethical standards (including the Helsinki Declaration and its amendments, institutional/national research committee standards, and international/national/institutional guidelines). Specifically, for nPOD samples, deceased human organ donor tissue samples were obtained and coded by nPOD under the University of Florida (UF) Institutional Review Board approved protocol IRB201600029 and processed by the Brusko Lab under protocol IRB201602502.

Open Access This article is distributed under the terms of the Creative Commons Attribution 4.0 International License (http:// creativecommons.org/licenses/by/4.0/), which permits unrestricted use, distribution, and reproduction in any medium, provided you give appropriate credit to the original author(s) and the source, provide a link to the Creative Commons license, and indicate if changes were made.

\section{References}

Papers of particular interest, published recently, have been highlighted as:

- Of importance

•- Of major importance

1. Wicker LS, Clark J, Fraser HI, Garner VE, Gonzalez-Munoz A, Healy B, et al. Type 1 diabetes genes and pathways shared by humans and NOD mice. J Autoimmun. 2005;25(Suppl):29-33. https://doi.org/10.1016/j.jaut.2005.09.009.

2. Giarratana N, Penna G, Adorini L. Animal models of spontaneous autoimmune disease: type 1 diabetes in the nonobese diabetic mouse. Methods Mol Biol. 2007;380:285-311. https://doi.org/ 10.1007/978-1-59745-395-0 17.

3. Sosinowski T, Eisenbarth GS. Type 1 diabetes: primary antigen/ peptide/register/trimolecular complex. Immunol Res. 2013;55(13):270-6. https://doi.org/10.1007/s12026-012-8367-6.
4. Boldison J, Wong FS. Immune and pancreatic beta cell interactions in type 1 diabetes. Trends Endocrinol Metab. 2016;27(12): 856-67. https://doi.org/10.1016/j.tem.2016.08.007.

5. Christianson SW, Shultz LD, Leiter EH. Adoptive transfer of diabetes into immunodeficient NOD-scid/scid mice. Relative contributions of CD4+ and CD8+ T-cells from diabetic versus prediabetic NOD.NON-Thy-1a donors. Diabetes. 1993;42(1):44-55.

6. Ikehara S, Ohtsuki H, Good RA, Asamoto H, Nakamura T, Sekita $\mathrm{K}$, et al. Prevention of type I diabetes in nonobese diabetic mice by allogenic bone marrow transplantation. Proc Natl Acad Sci U S A. 1985;82(22):7743-7.

7. Lampeter EF, Homberg M, Quabeck K, Schaefer UW, Wernet P, Bertrams J, et al. Transfer of insulin-dependent diabetes between HLA-identical siblings by bone marrow transplantation. Lancet. 1993;341(8855):1243-4.

8. Lampeter EF, McCann SR, Kolb H. Transfer of diabetes type 1 by bone-marrow transplantation. Lancet. 1998;351(9102):568-9. https://doi.org/10.1016/s0140-6736(05)78555-x.

9. Van Belle TL, Taylor P, von Herrath MG. Mouse models for type 1 diabetes. Drug Discov Today Dis Models. 2009;6(2):41-5. https://doi.org/10.1016/j.ddmod.2009.03.008.

10. Campbell-Thompson M, Fu A, Kaddis JS, Wasserfall C, Schatz DA, Pugliese A, et al. Insulitis and beta-cell mass in the natural history of type 1 diabetes. Diabetes. 2016;65(3):719-31. https:// doi.org/10.2337/db15-0779.

11. in't Veld P. Rodent versus human insulitis: why the huge disconnect? Curr Opin Endocrinol Diabetes Obes. 2015;22(2):86-90. https://doi.org/10.1097/med.0000000000000135.

12. In't Veld P. Insulitis in human type 1 diabetes: the quest for an elusive lesion. Islets. 2011;3(4):131-8.

13. Herold KC, Usmani-Brown S, Ghazi T, Lebastchi J, Beam CA, Bellin MD, et al. Beta cell death and dysfunction during type 1 diabetes development in at-risk individuals. J Clin Invest. 2015;125(3):1163-73. https://doi.org/10.1172/jci78142.

14. Atkinson MA, Bluestone JA, Eisenbarth GS, Hebrok M, Herold $\mathrm{KC}$, Accili D, et al. How does type 1 diabetes develop?: the notion of homicide or beta-cell suicide revisited. Diabetes. 2011;60(5): 1370-9. https://doi.org/10.2337/db10-1797.

15. Herold KC, Brooks-Worrell B, Palmer J, Dosch HM, Peakman M, Gottlieb P, et al. Validity and reproducibility of measurement of islet autoreactivity by T-cell assays in subjects with early type 1 diabetes. Diabetes. 2009;58(11):2588-95. https://doi.org/10.2337/ db09-0249.

16. Arif S, Leete P, Nguyen V, Marks K, Nor NM, Estorninho M, et al. Blood and islet phenotypes indicate immunological heterogeneity in type 1 diabetes. Diabetes. 2014;63(11):3835-45. https://doi. org/10.2337/db14-0365.

17. Roep BO, Atkinson MA, van Endert PM, Gottlieb PA, Wilson SB, Sachs JA. Autoreactive T cell responses in insulin-dependent (type 1) diabetes mellitus. Report of the first international workshop for standardization of T cell assays. J Autoimmun. 1999;13(2):26782. https://doi.org/10.1006/jaut.1999.0312 S0896-8411(99) 90312-8.

18. Mallone R, Scotto M, Janicki CN, James EA, Fitzgerald-Miller L, Wagner R, et al. Immunology of diabetes society T-cell workshop: HLA class I tetramer-directed epitope validation initiative T-cell workshop report-HLA class I tetramer validation initiative. Diabetes Metab Res Rev. 2011;27(8):720-6. https://doi.org/10. 1002/dmrr.1243.

19. Mannering SI, Wong FS, Durinovic-Belló I, Brooks-Worrell B, Tree TI, Cilio CM, et al. Current approaches to measuring human islet-antigen specific $\mathrm{T}$ cell function in type 1 diabetes. Clin Exp Immunol. 2010;162(2):197-209. https://doi.org/10.1111/j.13652249.2010.04237.x.

20. Thome J, Yudanin N, Ohmura Y, Kubota M, Grinshpun B, Sathaliyawala T, et al. Spatial map of human $\mathrm{T}$ cell 
compartmentalization and maintenance over decades of life. Cell. 2014;159(4):814-28.

21. Farber D, Yudanin N, Restifo N. Human memory T cells: generation, compartmentalization and homeostasis. Nature Rev Immunol. 2014;14(1):24-35.

22. Li L, He Q, Garland A, Yi Z, Aybar LT, Kepler TB, et al. Beta cellspecific CD4+ T cell clonotypes in peripheral blood and the pancreatic islets are distinct. J Immunol (Baltimore, Md : 1950). 2009;183(11):7585-91. https://doi.org/10.4049/jimmunol. 0901587.

23. Eugster A, Lindner A, Catani M, Heninger AK, Dahl A, Klemroth $\mathrm{S}$, et al. High diversity in the TCR repertoire of GAD65 autoantigen-specific human CD4+ T cells. J of Immunol (Baltimore, Md: 1950). 2015;194(6):2531-8. https://doi.org/10. 4049/jimmunol.1403031. This paper represents a comprehensive list of GAD65-reactive TCRs isolated by tetramer staining and then characterized via immunosequencing.

24. Fuchs YF, Eugster A, Dietz S, Sebelefsky C, Kuhn D, Wilhelm C, et al. CD8+ T cells specific for the islet autoantigen IGRP are restricted in their T cell receptor chain usage. Sci Rep. 2017;7: 44661. https://doi.org/10.1038/srep44661.

25. Skowera A, Ladell K, McLaren JE, Dolton G, Matthews KK, Gostick E, et al. Beta-cell-specific CD8 T cell phenotype in type 1 diabetes reflects chronic autoantigen exposure. Diabetes. 2015;64(3):916-25. https://doi.org/10.2337/db14-0332.

26. Erlich H, Valdes AM, Noble J, Carlson JA, Varney M, Concannon P, et al. HLA DR-DQ haplotypes and genotypes and type 1 diabetes risk: analysis of the type 1 diabetes genetics consortium families. Diabetes. 2008;57(4):1084-92. https://doi.org/10.2337/ db07-1331.

27. Jeker LT, Bour-Jordan H, Bluestone JA. Breakdown in peripheral tolerance in type 1 diabetes in mice and humans. Cold Spring Harb Perspect Med. 2012;2(3):a007807. https://doi.org/10.1101/ cshperspect.a007807.

28. Lempainen J, Laine AP, Hammais A, Toppari J, Simell O, Veijola $\mathrm{R}$, et al. Non-HLA gene effects on the disease process of type 1 diabetes: from HLA susceptibility to overt disease. J Autoimmun. 2015;61:45-53. https://doi.org/10.1016/j.jaut.2015.05.005.

29. Noble JA, Valdes AM. Genetics of the HLA region in the prediction of type 1 diabetes. Curr Diabetes Rep. 2011;11(6):533-42. https://doi.org/10.1007/s11892-011-0223-x.

30. Al-Hussein KA, Rama NR, Ahmad M, Rozemuller E, Tilanus MG. HLA-DPB $1 * 0401$ is associated with dominant protection against type 1 diabetes in the general Saudi population and in subjects with a high-risk DR/DQ haplotype. Eur J Immunogenet. 2003;30(2):115-9.

31. Kaddis JS, Pugliese A, Atkinson MA. A run on the biobank: what have we learned about type 1 diabetes from the nPOD tissue repository? Curr Opin Endocrinol Diabetes Obes. 2015;22(4): 290-5. https://doi.org/10.1097/med.0000000000000171.

32. In't Veld P, Lievens D, De Grijse J, Ling Z, Van der Auwera B, Pipeleers-Marichal M, et al. Screening for insulitis in adult autoantibody-positive organ donors. Diabetes. 2007;56(9):2400 4. https://doi.org/10.2337/db07-0416.

33. Willcox A, Richardson SJ, Bone AJ, Foulis AK, Morgan NG. Analysis of islet inflammation in human type 1 diabetes. Clin Exp Immunol. 2009;155(2):173-81. https://doi.org/10.1111/j. 1365-2249.2008.03860.x.

34. Coppieters KT, Dotta F, Amirian N, Campbell PD, Kay TW, Atkinson MA, et al. Demonstration of islet-autoreactive CD8 T cells in insulitic lesions from recent onset and long-term type 1 diabetes patients. J Exp Med. 2012;209(1):51-60. https://doi.org/ 10.1084/jem.20111187.

35. Tian J, Zekzer D, Lu Y, Dang H, Kaufman DL. B cells are crucial for determinant spreading of $\mathrm{T}$ cell autoimmunity among beta cell antigens in diabetes-prone nonobese diabetic mice. J Immunol. 2006;176(4):2654-61.

36. Burke GW 3rd, Vendrame F, Virdi SK, Ciancio G, Chen L, Ruiz P, et al. Lessons from pancreas transplantation in type 1 diabetes: recurrence of islet autoimmunity. Curr Diab Rep. 2015;15(12): 121. https://doi.org/10.1007/s11892-015-0691-5. This paper provides longitudinal descriptions of autoreactive $T$ cell clones appearing in conjunciton with autoantibodies in patients with recurring type 1 diabetes after pancreas transplant.

37. Roep BO, Peakman M. Antigen targets of type 1 diabetes autoimmunity. Cold Spring Harb Perspect Med. 2012;2(4):a007781. https://doi.org/10.1101/cshperspect.a007781.

38. Seay HR, Yusko E, Rothweiler SJ, Zhang L, Posgai AL, Campbell-Thompson M, et al. Tissue distribution and clonal diversity of the $\mathrm{T}$ and $\mathrm{B}$ cell repertoire in type 1 diabetes. JCI Insight. 2016;1(20):e88242. https://doi.org/10.1172/jci.insight. 88242. This paper represents the first report characterizing the adaptive immune repertoire in multiple organs and tissues isolated from type 1 diabetes versus control organ donors.

39. Unger WW, Velthuis J, Abreu JR, Laban S, Quinten E, Kester MG, et al. Discovery of low-affinity preproinsulin epitopes and detection of autoreactive CD8 T-cells using combinatorial MHC multimers. J Autoimmun. 2011;37(3):151-9. https://doi.org/10. 1016/j.jaut.2011.05.012.

40. Danke NA, Koelle DM, Yee C, Beheray S, Kwok WW. Autoreactive $\mathrm{T}$ cells in healthy individuals. J Immunol (Baltimore, Md: 1950). 2004;172(10):5967-72.

41. Reijonen H, Novak EJ, Kochik S, Heninger A, Liu AW, Kwok WW, et al. Detection of GAD65-specific T-cells by major histocompatibility complex class II tetramers in type 1 diabetic patients and at-risk subjects. Diabetes. 2002;51(5):1375-82. https://doi. org/10.2337/diabetes.51.5.1375.

42. Mallone R, Martinuzzi E, Blancou P, Novelli G, Afonso G, Dolz $\mathrm{M}$, et al. CD8+ T-cell responses identify beta-cell autoimmunity in human type 1 diabetes. Diabetes. 2007;56(3):613-21. https://doi. org/10.2337/db06-1419.

43. Han A, Glanville J, Hansmann L, Davis MM. Linking T-cell receptor sequence to functional phenotype at the single-cell level. Nat Biotechnol. 2014;32(7):684-92. https://doi.org/10.1038/nbt. 2938.

44. Reijonen H, Mallone R, Heninger AK, Laughlin EM, Kochik SA, Falk B, et al. GAD65-specific CD4+ T-cells with high antigen avidity are prevalent in peripheral blood of patients with type 1 diabetes. Diabetes. 2004;53(8):1987-94.

45. Gebe JA, Yue BB, Unrath KA, Falk BA, Nepom GT. Restricted autoantigen recognition associated with deletional and adaptive regulatory mechanisms. J Immunol (Baltimore, Md: 1950). 2009;183(1):59-65. https://doi.org/10.4049/jimmunol.0804046.

46. Codina-Busqueta E, Scholz E, Munoz-Torres PM, Roura-Mir C, Costa $\mathrm{M}$, Xufre C, et al. TCR bias of in vivo expanded T cells in pancreatic islets and spleen at the onset in human type 1 diabetes. $\mathrm{J}$ Immunol (Baltimore, Md: 1950). 2011;186(6):3787-97. https:// doi.org/10.4049/jimmunol.1002423.

47. Marrero I, Aguilera C, Hamm DE, Quinn A, Kumar V. Highthroughput sequencing reveals restricted TCR Vbeta usage and public TCRbeta clonotypes among pancreatic lymph node memory CD4(+) T cells and their involvement in autoimmune diabetes. Mol Immunol. 2016;74:82-95. https://doi.org/10.1016/j.molimm. 2016.04.013.

48. Klarenbeek PL, de Hair MJ, Doorenspleet ME, van Schaik BD, Esveldt RE, van de Sande MG, et al. Inflamed target tissue provides a specific niche for highly expanded T-cell clones in early human autoimmune disease. Ann Rheum Dis. 2012;71(6):108893. https://doi.org/10.1136/annrheumdis-2011-200612. 
49. Kloverpris HN, McGregor R, McLaren JE, Ladell K, Harndahl M, Stryhn A, et al. CD8+ TCR bias and immunodominance in HIV-1 infection. J Immunol. 2015;194(11):5329-45. https://doi.org/10. 4049/jimmunol.1400854.

50. Wieckowski S, Baumgaertner P, Corthesy P, Voelter V, Romero P, Speiser DE, et al. Fine structural variations of alphabetaTCRs selected by vaccination with natural versus altered self-antigen in melanoma patients. J Immunol. 2009;183(8):5397-406. https:// doi.org/10.4049/jimmunol.0901460.

51. Niu J, Jia Q, Ni Q, Yang Y, Chen G, Yang X, et al. Association of CD8(+) T lymphocyte repertoire spreading with the severity of DRESS syndrome. Sci Rep. 2015;5:9913. https://doi.org/10. 1038/srep09913.

52. Cukalac T, Kan WT, Dash P, Guan J, Quinn KM, Gras S, et al. Paired TCRalphabeta analysis of virus-specific CD8(+) T cells exposes diversity in a previously defined 'narrow' repertoire. Immunol Cell Biol. 2015;93(9):804-14. https://doi.org/10.1038/ icb.2015.44.

53. Koning D, Costa AI, Hasrat R, Grady BP, Spijkers S, Nanlohy N, et al. In vitro expansion of antigen-specific CD8(+) T cells distorts the T-cell repertoire. J Immunol Methods. 2014;405:199-203. https://doi.org/10.1016/j.jim.2014.01.013.

54. Miconnet I, Marrau A, Farina A, Taffe P, Vigano S, Harari A, et al. Large TCR diversity of virus-specific CD8 T cells provides the mechanistic basis for massive TCR renewal after antigen exposure. J Immunol. 2011;186(12):7039-49. https://doi.org/10.4049/ jimmunol.1003309.

55. Remmerswaal EB, Klarenbeek PL, Alves NL, Doorenspleet ME, van Schaik BD, Esveldt RE, et al. Clonal evolution of CD8+ T cell responses against latent viruses: relationship among phenotype, localization, and function. J Virol. 2015;89(1):568-80. https:// doi.org/10.1128/jvi.02003-14.

56. Nakanishi K, Kukita Y, Segawa H, Inoue N, Ohue M, Kato K. Characterization of the T-cell receptor beta chain repertoire in tumor-infiltrating lymphocytes. Cancer Med. 2016;5(9):251321. https://doi.org/10.1002/cam4.828.

57. Kent SC, Chen Y, Bregoli L, Clemmings SM, Kenyon NS, Ricordi $\mathrm{C}$, et al. Expanded T cells from pancreatic lymph nodes of type 1 diabetic subjects recognize an insulin epitope. Nature. 2005;435(7039):224-8. https://doi.org/10.1038/nature03625.

58. Gil A, Yassai MB, Naumov YN, Selin LK. Narrowing of human influenza A virus-specific T cell receptor alpha and beta repertoires with increasing age. J Virol. 2015;89(8):4102-16. https://doi.org/ 10.1128/jvi.03020-14.

59. Conrad JA, Ramalingam RK, Smith RM, Barnett L, Lorey SL, Wei J, et al. Dominant clonotypes within HIV-specific T cell responses are programmed death-1high and CD127low and display reduced variant cross-reactivity. J Immunol. 2011;186(12):687185. https://doi.org/10.4049/jimmunol.1004234.

60. Salou M, Garcia A, Michel L, Gainche-Salmon A, Loussouarn D, Nicol B, et al. Expanded CD8 T-cell sharing between periphery and CNS in multiple sclerosis. Ann Clin Transl Neurol. 2015;2(6): 609-22. https://doi.org/10.1002/acn3.199.

61. Kitaura K, Fujii Y, Hayasaka D, Matsutani T, Shirai K, Nagata N, et al. High clonality of virus-specific $\mathrm{T}$ lymphocytes defined by TCR usage in the brains of mice infected with West Nile virus. $\mathrm{J}$ Immunol. 2011;187(8):3919-30. https://doi.org/10.4049/ jimmunol.1100442.

62. Miles JJ, Thammanichanond D, Moneer S, Nivarthi UK, KjerNielsen L, Tracy SL, et al. Antigen-driven patterns of TCR bias are shared across diverse outcomes of human hepatitis $\mathrm{C}$ virus infection. J Immunol. 2011;186(2):901-12. https://doi.org/10. 4049/jimmunol.1003167.

63. Toivonen R, Arstila TP, Hanninen A. Islet-associated T-cell receptor-beta CDR sequence repertoire in prediabetic NOD mice reveals antigen-driven T-cell expansion and shared usage of
VbetaJbeta TCR chains. Mol Immunol. 2015;64(1):127-35. https://doi.org/10.1016/j.molimm.2014.11.009.

64. Raffegerst SH, Hoelzlwimmer G, Kunder S, Mysliwietz J, Quintanilla-Martinez L, Schendel DJ. Diverse hematological malignancies including Hodgkin-like lymphomas develop in chimeric MHC class II transgenic mice. PLoS One. 2009;4(12):e8539. https://doi.org/10.1371/journal.pone.0008539.

65. Yu XG, Lichterfeld M, Chetty S, Williams KL, Mui SK, Miura T, et al. Mutually exclusive T-cell receptor induction and differential susceptibility to human immunodeficiency virus type 1 mutational escape associated with a two-amino-acid difference between HLA class I subtypes. J Virol. 2007;81(4):1619-31. https://doi.org/10. 1128/jvi.01580-06.

66. Zang Y, Martinez L, Fernandez I, Pignac-Kobinger J, Greidinger EL. Conservation of pathogenic TCR homology across class II restrictions in anti-ribonucleoprotein autoimmunity: extended efficacy of T cell vaccine therapy. J Immunol. 2014;192(9):4093102. https://doi.org/10.4049/jimmunol.1203197.

67. Gros A, Robbins PF, Yao X, Li YF, Turcotte S, Tran E, et al. PD-1 identifies the patient-specific CD8(+) tumor-reactive repertoire infiltrating human tumors. J Clin Invest. 2014;124(5):2246-59. https://doi.org/10.1172/jci73639.

68. Zhang Q, Jia Q, Deng T, Song B, Li L. Heterogeneous expansion of CD4+ tumor-infiltrating T-lymphocytes in clear cell renal cell carcinomas. Biochem Biophys Res Commun. 2015;458(1):70-6. https://doi.org/10.1016/j.bbrc.2015.01.069.

69. Mamedov IZ, Britanova OV, Bolotin DA, Chkalina AV, Staroverov DB, Zvyagin IV, et al. Quantitative tracking of T cell clones after haematopoietic stem cell transplantation. EMBO Mol Med. 2011;3(4):201-7. https://doi.org/10.1002/emmm. 201100129

70. Dong L, Li P, Oenema T, McClurkan CL, Koelle DM. Public TCR use by herpes simplex virus-2-specific human CD8 CTLs. J Immunol. 2010;184(6):3063-71. https://doi.org/10.4049/ jimmunol.0903622.

71. Jensen T, Hansen P, Faurskov Nielsen A, Meldal M, Komba S, Werdelin O. Shared structural motifs in TCR of glycopeptiderecognizing T cell hybridomas. Eur J Immunol. 1999;29(9): 2759-68. https://doi.org/10.1002/(sici)1521-4141(199909)29: 09<2759::aid-immu2759>3.0.co;2-4.

72. Price DA, Brenchley JM, Ruff LE, Betts MR, Hill BJ, Roederer $\mathrm{M}$, et al. Avidity for antigen shapes clonal dominance in CD8+ T cell populations specific for persistent DNA viruses. J Exp Med. 2005;202(10):1349-61. https://doi.org/10.1084/jem.20051357.

73. La Gruta NL, Thomas PG, Webb AI, Dunstone MA, Cukalac T, Doherty PC, et al. Epitope-specific TCRbeta repertoire diversity imparts no functional advantage on the CD8+ T cell response to cognate viral peptides. Proc Natl Acad Sci U S A. 2008;105(6): 2034-9. https://doi.org/10.1073/pnas.0711682102.

74. Klarenbeek PL, Remmerswaal EB, ten Berge IJ, Doorenspleet ME, van Schaik BD, Esveldt RE, et al. Deep sequencing of antiviral T-cell responses to HCMV and EBV in humans reveals a stable repertoire that is maintained for many years. PLoS Pathog. 2012;8(9):e1002889. https://doi.org/10.1371/journal. ppat.1002889.

75. Rangarajan H, Yassai M, Subramanian H, Komorowski R, Whitaker M, Gorski J, et al. Emergence of T cells that recognize nonpolymorphic antigens during graft-versus-host disease. Blood. 2012;119(26):6354-64. https://doi.org/10.1182/blood-2012-01401596.

76. Cohen GB, Islam SA, Noble MS, Lau C, Brander C, Altfeld MA, et al. Clonotype tracking of TCR repertoires during chronic virus infections. Virology. 2002;304(2):474-84.

77. Simons BC, Vancompernolle SE, Smith RM, Wei J, Barnett L, Lorey SL, et al. Despite biased TRBV gene usage against a dominant HLA B57-restricted epitope, TCR diversity can provide 
recognition of circulating epitope variants. J Immunol. 2008;181(7):5137-46.

78. Serana F, Sottini A, Caimi L, Palermo B, Natali PG, Nistico P, et al. Identification of a public CDR3 motif and a biased utilization of T-cell receptor $\mathrm{V}$ beta and $\mathrm{J}$ beta chains in HLA-A2/Melan-Aspecific T-cell clonotypes of melanoma patients. J Transl Med. 2009;7:21. https://doi.org/10.1186/1479-5876-7-21.

79. Iglesias MC, Almeida JR, Fastenackels S, van Bockel DJ, Hashimoto M, Venturi V, et al. Escape from highly effective public CD8+ T-cell clonotypes by HIV. Blood. 2011;118(8):2138-49. https://doi.org/10.1182/blood-2011-01-328781.

80. Sonntag K, Eckert F, Welker C, Muller H, Muller F, Zips D, et al. Chronic graft-versus-host-disease in CD34(+)-humanized NSG mice is associated with human susceptibility HLA haplotypes for autoimmune disease. J Autoimmun. 2015;62:55-66. https:// doi.org/10.1016/j.jaut.2015.06.006.

81. Palermo B, Del Bello D, Sottini A, Serana F, Ghidini C, Gualtieri $\mathrm{N}$, et al. Dacarbazine treatment before peptide vaccination enlarges T-cell repertoire diversity of melan-a-specific, tumorreactive CTL in melanoma patients. Cancer Rses. 2010;70(18): 7084-92. https://doi.org/10.1158/0008-5472.can-10-1326.

82. Kedzierska K, Venturi V, Field K, Davenport MP, Turner SJ, Doherty PC. Early establishment of diverse T cell receptor profiles for influenza-specific CD8(+)CD62L(hi) memory T cells. Proc Natl Acad Sci U S A. 2006;103(24):9184-9. https://doi.org/10. 1073/pnas.0603289103.

83. Sun X, Fujiwara M, Shi Y, Kuse N, Gatanaga H, Appay V, et al. Superimposed epitopes restricted by the same HLA molecule drive distinct HIV-specific CD8+ T cell repertoires. J Immunol. 2014;193(1):77-84. https://doi.org/10.4049/jimmunol.1400375.

84. Chung WH, Pan RY, Chu MT, Chin SW, Huang YL, Wang WC, et al. Oxypurinol-specific T cells possess preferential TCR clonotypes and express granulysin in allopurinol-induced severe cutaneous adverse reactions. J Invest Dermatol. 2015;135(9): 2237-48. https://doi.org/10.1038/jid.2015.165.

85. Casanova JL, Romero P, Widmann C, Kourilsky P, Maryanski JL. $T$ cell receptor genes in a series of class I major histocompatibility complex-restricted cytotoxic $\mathrm{T}$ lymphocyte clones specific for a plasmodium berghei nonapeptide: implications for T cell allelic exclusion and antigen-specific repertoire. J Exp Med. 1991;174(6):1371-83.

86. Trautmann L, Rimbert M, Echasserieau K, Saulquin X, Neveu B, Dechanet J, et al. Selection of T cell clones expressing highaffinity public TCRs within human cytomegalovirus-specific CD8 T cell responses. J Immunol. 2005;175(9):6123-32.

87. Sainz-Perez A, Lim A, Lemercier B, Leclerc C. The T-cell receptor repertoire of tumor-infiltrating regulatory $\mathrm{T}$ lymphocytes is skewed toward public sequences. Cancer Res. 2012;72(14): 3557-69. https://doi.org/10.1158/0008-5472.can-12-0277.

88. Iancu EM, Corthesy P, Baumgaertner P, Devevre E, Voelter V, Romero P, et al. Clonotype selection and composition of human CD8 T cells specific for persistent herpes viruses varies with differentiation but is stable over time. J Immunol. 2009;183(1):31931. https://doi.org/10.4049/jimmunol.0803647.

89. Sherwood AM, Emerson RO, Scherer D, Habermann N, Buck K, Staffa J, et al. Tumor-infiltrating lymphocytes in colorectal tumors display a diversity of $\mathrm{T}$ cell receptor sequences that differ from the $\mathrm{T}$ cells in adjacent mucosal tissue. Cancer Immunol Immunother. 2013;62(9):1453-61. https://doi.org/10.1007/s00262-013-14462.

90. Motz GT, Eppert BL, Sun G, Wesselkamper SC, Linke MJ, Deka $\mathrm{R}$, et al. Persistence of lung CD8 T cell oligoclonal expansions upon smoking cessation in a mouse model of cigarette smokeinduced emphysema. J Immunol. 2008;181(11):8036-43.

91. Costello PJ, Winchester RJ, Curran SA, Peterson KS, Kane DJ, Bresnihan B, et al. Psoriatic arthritis joint fluids are characterized by $\mathrm{CD} 8$ and $\mathrm{CD} 4 \mathrm{~T}$ cell clonal expansions appear antigen driven. $\mathrm{J}$ Immunol. 2001;166(4):2878-86.

92. Wu HD, Maurer MS, Friedman RA, Marboe CC, Ruiz-Vazquez EM, Ramakrishnan R, et al. The lymphocytic infiltration in calcific aortic stenosis predominantly consists of clonally expanded $\mathrm{T}$ cells. J Immunol. 2007;178(8):5329-39.

93. Miles JJ, Bulek AM, Cole DK, Gostick E, Schauenburg AJ, Dolton $\mathrm{G}$, et al. Genetic and structural basis for selection of a ubiquitous T cell receptor deployed in Epstein-Barr virus infection. PLoS Pathog. 2010;6(11):e1001198. https://doi.org/10.1371/ journal.ppat.1001198.

94. Chen G, Yang X, Ko A, Sun X, Gao M, Zhang Y, et al. Sequence and structural analyses reveal distinct and highly diverse human CD8+ TCR repertoires to immunodominant viral antigens. Cell Rep. 2017;19(3):569-83. https://doi.org/10.1016/j.celrep.2017. 03.072 .

95. Wallace ME, Bryden M, Cose SC, Coles RM, Schumacher TN, Brooks A, et al. Junctional biases in the naive TCR repertoire control the CTL response to an immunodominant determinant of HSV-1. Immunity. 2000;12(5):547-56.

96. Protheroe AS, Pickard C, Johnson PW, Craddock T, Shefta J, Short K, et al. Persistence of clonal T-cell expansions following high-dose chemotherapy and autologous peripheral blood progenitor cell rescue. Br J Haematol. 2000;111(3):766-73.

97. Manne J, Mastrangelo MJ, Sato T, Berd D. TCR rearrangement in lymphocytes infiltrating melanoma metastases after administration of autologous dinitrophenyl-modified vaccine. J Immunol. 2002;169(6):3407-12.

98. Nakasone H, Tanaka Y, Yamazaki R, Terasako K, Sato M, Sakamoto K, et al. Single-cell T-cell receptor-beta analysis of HLA-A*2402-restricted CMV- pp65-specific cytotoxic T-cells in allogeneic hematopoietic SCT. Bone Marrow Transplant. 2014;49(1):87-94. https://doi.org/10.1038/bmt.2013.122.

99. Kedzierska K, Turner SJ, Doherty PC. Conserved T cell receptor usage in primary and recall responses to an immunodominant influenza virus nucleoprotein epitope. Proc Natl Acad Sci U S A. 2004;101(14):4942-7. https://doi.org/10.1073/pnas. 0401279101

100. Li LP, Lampert JC, Chen X, Leitao C, Popovic J, Muller W, et al. Transgenic mice with a diverse human $\mathrm{T}$ cell antigen receptor repertoire. Nat Med. 2010;16(9):1029-34. https://doi.org/10. 1038/nm.2197.

101. Klinger M, Pepin F, Wilkins J, Asbury T, Wittkop T, Zheng J, et al. Multiplex identification of antigen-specific T cell receptors using a combination of immune assays and immune receptor sequencing. PLoS One. 2015;10(10):e0141561. https://doi.org/10.1371/ journal.pone. 0141561 .

102. Munson DJ, Egelston CA, Chiotti KE, Parra ZE, Bruno TC, Moore BL, et al. Identification of shared TCR sequences from T cells in human breast cancer using emulsion RT-PCR. Proc Natl Acad Sci U S A. 2016;113(29):8272-7. https://doi.org/10.1073/ pnas. 1606994113.

103. Osman GE, Toda M, Kanagawa O, Hood LE. Characterization of the $\mathrm{T}$ cell receptor repertoire causing collagen arthritis in mice. $\mathrm{J}$ Exp Med. 1993;177(2):387-95.

104. Venturi V, Chin HY, Asher TE, Ladell K, Scheinberg P, Bornstein $\mathrm{E}$, et al. TCR beta-chain sharing in human CD8+ T cell responses to cytomegalovirus and EBV. J Immunol. 2008;181(11):7853-62.

105. Sensi M, Farina C, Maccalli C, Lupetti R, Nicolini G, Anichini A, et al. Clonal expansion of $\mathrm{T}$ lymphocytes in human melanoma metastases after treatment with a hapten-modified autologous tumor vaccine. J Clin Invest. 1997;99(4):710-7. https://doi.org/10. 1172/jci119215.

106. Lim A, Trautmann L, Peyrat MA, Couedel C, Davodeau F, Romagne F, et al. Frequent contribution of T cell clonotypes with public TCR features to the chronic response against a dominant 
EBV-derived epitope: application to direct detection of their molecular imprint on the human peripheral $\mathrm{T}$ cell repertoire. $\mathrm{J}$ Immunol. 2000;165(4):2001-11.

107. Adams S, Leblanc P, Datta SK. Junctional region sequences of Tcell receptor beta-chain genes expressed by pathogenic anti-DNA autoantibody-inducing helper T cells from lupus mice: possible selection by cationic autoantigens. Proc Natl Acad Sci U S A. 1991;88(24):11271-5.

108. Johnston SL, Borson ND, Wettstein PJ. Spectratyping of TCRs expressed by CTL-infiltrating minor histocompatibility antigendisparate allografts. J Immunol. 1997;159(11):5233-45.

109. Willhauck M, Scheibenbogen C, Pawlita M, Mohler T, Thiel E, Keilholz U. Restricted T-cell receptor repertoire in melanoma metastases regressing after cytokine therapy. Cancer Res. 2003;63(13):3483-5.

110. Nicolo C, Di Sante G, Orsini M, Rolla S, Columba-Cabezas S, Romano Spica V, et al. Mycobacterium tuberculosis in the adjuvant modulates the balance of Th immune response to self-antigen of the CNS without influencing a "core" repertoire of specific T cells. Int Immunol. 2006;18(2):363-74. https://doi.org/10.1093/ intimm/dxh376.

111. Fujii Y, Hayasaka D, Kitaura K, Takasaki T, Suzuki R, Kurane I. Tcell clones expressing different T-cell receptors accumulate in the brains of dying and surviving mice after peripheral infection with far eastern strain of tick-borne encephalitis virus. Viral Immunol. 2011;24(4):291-302. https://doi.org/10.1089/vim.2011.0017.

112. Aas-Hanssen K, Funderud A, Thompson KM, Bogen B, Munthe LA. Idiotype-specific Th cells support oligoclonal expansion of anti-dsDNA B cells in mice with lupus. J Immunol. 2014;193(6):2691-8. https://doi.org/10.4049/jimmunol.1400640.

113. Hill BJ, Darrah PA, Ende Z, Ambrozak DR, Quinn KM, Darko S, et al. Epitope specificity delimits the functional capabilities of vaccine-induced CD $8 \mathrm{~T}$ cell populations. J Immunol. 2014;193(11):5626-36. https://doi.org/10.4049/jimmunol. 1401017.

114. Shirai K, Hayasaka D, Kitaura K, Takasaki T, Morita K, Suzuki R, et al. Qualitative differences in brain-infiltrating T cells are associated with a fatal outcome in mice infected with Japanese encephalitis virus. Arch Virol. 2015;160(3):765-75. https://doi.org/10. 1007/s00705-014-2154-8.

115. Miyai M, Eikawa S, Hosoi A, Iino T, Matsushita H, Isobe M, et al. Detection and tracking of NY-ESO-1-specific CD8+ T cells by high-throughput $\mathrm{T}$ cell receptor beta (TCRB) gene rearrangements sequencing in a peptide-vaccinated patient. PLoS One. 2015;10(8):e0136086. https://doi.org/10.1371/journal.pone. 0136086.

116. Campos-Lima PO, Levitsky V, Imreh MP, Gavioli R, Masucci MG. Epitope-dependent selection of highly restricted or diverse $\mathrm{T}$ cell receptor repertoires in response to persistent infection by Epstein-Barr virus. J Exp Med. 1997;186(1):83-9.

117. Slachta CA, Jeevanandam V, Goldman B, Lin WL, Platsoucas CD. Coronary arteries from human cardiac allografts with chronic rejection contain oligoclonal T cells: persistence of identical clonally expanded TCR transcripts from the early post-transplantation period (endomyocardial biopsies) to chronic rejection (coronary arteries). J Immunol. 2000;165(6):3469-83.

118. Boita M, Guida G, Circosta P, Elia AR, Stella S, Heffler E, et al. The molecular and functional characterization of clonally expanded CD8+ TCR BV T cells in eosinophilic granulomatosis with polyangiitis (EGPA). Clin Immunol. 2014;152(1-2):152-63. https://doi.org/10.1016/j.clim.2014.03.001.

119. Brandle D, Burki K, Wallace VA, Rohrer UH, Mak TW, Malissen $\mathrm{B}$, et al. Involvement of both $\mathrm{T}$ cell receptor $\mathrm{V}$ alpha and $\mathrm{V}$ beta variable region domains and alpha chain junctional region in viral antigen recognition. Eur J Immunol. 1991;21(9):2195-202. https://doi.org/10.1002/eji.1830210930.
120. Clemente MJ, Przychodzen B, Jerez A, Dienes BE, Afable MG, Husseinzadeh $\mathrm{H}$, et al. Deep sequencing of the T-cell receptor repertoire in CD8+ T-large granular lymphocyte leukemia identifies signature landscapes. Blood. 2013;122(25):4077-85. https:// doi.org/10.1182/blood-2013-05-506386.

121. Iancu EM, Gannon PO, Laurent J, Gupta B, Romero P, Michielin $\mathrm{O}$, et al. Persistence of EBV antigen-specific CD8 T cell clonotypes during homeostatic immune reconstitution in cancer patients. PLoS One. 2013;8(10):e78686. https://doi.org/10.1371/ journal.pone.0078686.

122. Bowerman NA, Falta MT, Mack DG, Wehrmann F, Crawford F, Mroz MM, et al. Identification of multiple public TCR repertoires in chronic beryllium disease. J Immunol. 2014;192(10):4571-80. https://doi.org/10.4049/jimmunol.1400007.

123. Echchakir H, Asselin-Paturel C, Dorothee G, Vergnon I, Grunenwald D, Chouaib S, et al. Analysis of T-cell-receptor beta-chain-gene usage in peripheral-blood and tumor-infiltrating lymphocytes from human non-small-cell lung carcinomas. Int $\mathbf{J}$ Cancer. 1999;81(2):205-13.

124. Nguyen P, Liu W, Ma J, Manirarora JN, Liu X, Cheng C, et al. Discrete TCR repertoires and CDR3 features distinguish effector and Foxp3+ regulatory $\mathrm{T}$ lymphocytes in myelin oligodendrocyte glycoprotein-induced experimental allergic encephalomyelitis. J Immunol. 2010;185(7):3895-904. https://doi.org/10.4049/ jimmunol.1001550.

125. Sensi M, Traversari C, Radrizzani M, Salvi S, Maccalli C, Mortarini R, et al. Cytotoxic T-lymphocyte clones from different patients display limited T-cell-receptor variable-region gene usage in HLA-A2-restricted recognition of the melanoma antigen Melan-A/MART-1. Proc Natl Acad Sci U S A. 1995;92(12): 5674-8.

126. Goebels N, Hofstetter H, Schmidt S, Brunner C, Wekerle H, Hohlfeld R. Repertoire dynamics of autoreactive T cells in multiple sclerosis patients and healthy subjects: epitope spreading versus clonal persistence. Brain. 2000;123(Pt 3):508-18.

127. Berger CT, Frahm N, Price DA, Mothe B, Ghebremichael M, Hartman KL, et al. High-functional-avidity cytotoxic T lymphocyte responses to HLA-B-restricted Gag-derived epitopes associated with relative HIV control. J Virol. 2011;85(18):9334-45. https://doi.org/10.1128/jvi.00460-11.

128. Hunsucker SA, McGary CS, Vincent BG, Enyenihi AA, Waugh JP, McKinnon KP, et al. Peptide/MHC tetramer-based sorting of CD8(+) T cells to a leukemia antigen yields clonotypes drawn nonspecifically from an underlying restricted repertoire. Cancer Immunol Res. 2015;3(3):228-35. https://doi.org/10.1158/23266066.cir-14-0001.

129. Wang F, Ono T, Kalergis AM, Zhang W, DiLorenzo TP, Lim K, et al. On defining the rules for interactions between the $\mathrm{T}$ cell receptor and its ligand: a critical role for a specific amino acid residue of the T cell receptor beta chain. Proc Natl Acad Sci U S A. 1998;95(9):5217-22.

130. Rizzuto GA, Merghoub T, Hirschhorn-Cymerman D, Liu C, Lesokhin AM, Sahawneh D, et al. Self-antigen-specific CD8+ T cell precursor frequency determines the quality of the antitumor immune response. J Exp Med. 2009;206(4):849-66. https://doi. org/10.1084/jem.20081382.

131. Luo W, Ma L, Wen Q, Zhou M, Wang X. Analysis of the conservation of $\mathrm{T}$ cell receptor alpha and beta chain variable regions gene in pp65 peptide-specific HLA-A*0201-restricted CD8+ T cells. Cell Mol Immunol. 2009;6(2):105-10. https://doi.org/10.1038/ cmi.2009.14.

132. Dahal-Koirala S, Risnes LF, Christophersen A, Sarna VK, Lundin $\mathrm{KE}$, Sollid LM, et al. TCR sequencing of single cells reactive to DQ2.5-glia-alpha2 and DQ2.5-glia-omega2 reveals clonal expansion and epitope-specific V-gene usage. Mucosal Immunol. 2016;9(3):587-96. https://doi.org/10.1038/mi.2015.147. 
133. Mackensen A, Ferradini L, Carcelain G, Triebel F, Faure F, Viel S, et al. Evidence for in situ amplification of cytotoxic Tlymphocytes with antitumor activity in a human regressive melanoma. Cancer Res. 1993;53(15):3569-73.

134. Fazou C, Yang H, McMichael AJ, Callan MF. Epitope specificity of clonally expanded populations of CD8+ T cells found within the joints of patients with inflammatory arthritis. Arthritis Rheum. 2001;44(9):2038-45. https://doi.org/10.1002/1529-0131(200109) 44:9<2038::aid-art353>3.0.co;2-1

135. Zhong W, Reinherz EL. In vivo selection of a TCR Vbeta repertoire directed against an immunodominant influenza virus CTL epitope. Int Immunol. 2004;16(11):1549-59. https://doi.org/10. 1093/intimm/dxh156.

136. Clemens EB, Doherty PC, La Gruta NL, Turner SJ. Fixed expression of single influenza virus-specific TCR chains demonstrates the capacity for TCR alpha- and beta-chain diversity in the face of peptide-MHC class I specificity. J Immunol. 2015;194(3):898910. https://doi.org/10.4049/jimmunol.1401792.

137. Iwashiro M, Kondo T, Shimizu T, Yamagishi H, Takahashi K, Matsubayashi Y, et al. Multiplicity of virus-encoded helper Tcell epitopes expressed on FBL-3 tumor cells. J Virol. 1993;67(8):4533-42.

138. Ferradini L, Mackensen A, Genevee C, Bosq J, Duvillard P, Avril $\mathrm{MF}$, et al. Analysis of T cell receptor variability in tumorinfiltrating lymphocytes from a human regressive melanoma. Evidence for in situ $\mathrm{T}$ cell clonal expansion. J Clin Invest. 1993;91(3):1183-90. https://doi.org/10.1172/jci116278.

139. McKee MD, Clay TM, Diamond RA, Rosenberg SA, Nishimura MI. Quantitation of T-cell receptor frequencies by competitive polymerase chain reaction: dynamics of T-cell clonotype frequencies in an expanding tumor-infiltrating lymphocyte culture. J Immunother. 2000;23(4):419-29.

140. Menezes JS, van den Elzen P, Thornes J, Huffman D, Droin NM, Maverakis E, et al. A public T cell clonotype within a heterogeneous autoreactive repertoire is dominant in driving EAE. J Clin Invest. 2007;117(8):2176-85. https://doi.org/10.1172/jci28277.

141. Nakano N, Kikutani H, Nishimoto H, Kishimoto T. T cell receptor $\mathrm{V}$ gene usage of islet beta cell-reactive T cells is not restricted in non-obese diabetic mice. J Exp Med. 1991;173(5):1091-7.

142. Shilyansky J, Nishimura MI, Yannelli JR, Kawakami Y, Jacknin LS, Charmley P, et al. T-cell receptor usage by melanoma-specific clonal and highly oligoclonal tumor-infiltrating lymphocyte lines. Proc Natl Acad Sci U S A. 1994;91(7):2829-33.

143. Deckhut AM, Allan W, McMickle A, Eichelberger M, Blackman MA, Doherty PC, et al. Prominent usage of V beta $8.3 \mathrm{~T}$ cells in the $\mathrm{H}-2 \mathrm{Db}$-restricted response to an influenza A virus nucleoprotein epitope. J Immunol. 1993;151(5):2658-66.

144. Sensi M, Salvi S, Castelli C, Maccalli C, Mazzocchi A, Mortarini $\mathrm{R}$, et al. T cell receptor (TCR) structure of autologous melanomareactive cytotoxic T lymphocyte (CTL) clones: tumor-infiltrating lymphocytes overexpress in vivo the TCR beta chain sequence used by an HLA-A2-restricted and melanocyte-lineage-specific CTL clone. J Exp Med. 1993;178(4):1231-46.

145. Farina C, van der Bruggen P, Boel P, Parmiani G, Sensi M. Conserved TCR usage by HLA-Cw* 1601-restricted T cell clones recognizing melanoma antigens. Int Immunol. 1996;8(9):1463-6.

146. Skulina C, Schmidt S, Dornmair K, Babbe H, Roers A, Rajewsky $\mathrm{K}$, et al. Multiple sclerosis: brain-infiltrating CD8+ T cells persist as clonal expansions in the cerebrospinal fluid and blood. Proc Natl Acad Sci U S A. 2004;101(8):2428-33.

147. Robins HS, Srivastava SK, Campregher PV, Turtle CJ, Andriesen J, Riddell SR, et al. Overlap and effective size of the human CD8+ T cell receptor repertoire. Sci Transl Med. 2010;2(47):47ra64. https://doi.org/10.1126/scitranslmed.3001442.

148. Peggs K, Verfuerth S, Pizzey A, Ainsworth J, Moss P, Mackinnon S. Characterization of human cytomegalovirus peptide-specific
CD8(+) T-cell repertoire diversity following in vitro restimulation by antigen-pulsed dendritic cells. Blood. 2002;99(1):213-23.

149. Zhou J, Dudley ME, Rosenberg SA, Robbins PF. Selective growth, in vitro and in vivo, of individual $\mathrm{T}$ cell clones from tumor-infiltrating lymphocytes obtained from patients with melanoma. J Immunol. 2004;173(12):7622-9.

150. Muraro PA, Robins H, Malhotra S, Howell M, Phippard D, Desmarais $\mathrm{C}$, et al. $\mathrm{T}$ cell repertoire following autologous stem cell transplantation for multiple sclerosis. J Clin Invest. 2014;124(3):1168-72. https://doi.org/10.1172/jci71691.

151. Viret C, Mahiddine K, Baker RL, Haskins K, Guerder S. The T cell repertoire-diversifying enzyme TSSP contributes to thymic selection of diabetogenic CD4 $\mathrm{T}$ cell specificities reactive to ChgA and IAPP autoantigens. J Immunol. 2015;195(5):1964 73. https://doi.org/10.4049/jimmunol.1401683.

152. Eltahla AA, Rizzetto S, Pirozyan MR, Betz-Stablein BD, Venturi $\mathrm{V}$, Kedzierska K, et al. Linking the T cell receptor to the single cell transcriptome in antigen-specific human $\mathrm{T}$ cells. Immunol Cell Biol. 2016;94(6):604-11. https://doi.org/10.1038/icb.2016.16.

153. Durinovic-Bello I, Steinle A, Ziegler AG, Schendel DJ. HLA-DQrestricted, islet-specific T-cell clones of a type I diabetic patient. Tcell receptor sequence similarities to insulitis-inducing T-cells of nonobese diabetic mice. Diabetes. 1994;43(11):1318-25.

154. Echchakir H, Vergnon I, Dorothee G, Grunenwald D, Chouaib S, Mami-Chouaib F. Evidence for in situ expansion of diverse antitumor-specific cytotoxic T lymphocyte clones in a human large cell carcinoma of the lung. Int Immunol. 2000;12(4):537-46.

155. Hamel Y, Rohrlich P, Baron V, Bonhomme D, Rieux-Laucat F, Necker A, et al. Characterization of antigen-specific repertoire diversity following in vitro restimulation by a recombinant adenovirus expressing human cytomegalovirus pp65. Eur J Immunol. 2003;33(3):760-8. https://doi.org/10.1002/eji.200323628.

156. Kuball J, Schmitz FW, Voss RH, Ferreira EA, Engel R, Guillaume $\mathrm{P}$, et al. Cooperation of human tumor-reactive CD4+ and CD8+ T cells after redirection of their specificity by a high-affinity p53A2.1-specific TCR. Immunity. 2005;22(1):117-29. https:// doi.org/10.1016/j.immuni.2004.12.005.

157. Marino M, Maiuri MT, Di Sante G, Scuderi F, La Carpia F, Trakas $\mathrm{N}$, et al. T cell repertoire in DQ5-positive MuSK-positive myasthenia gravis patients. J Autoimmun. 2014;52:113-21. https://doi. org/10.1016/j.jaut.2013.12.007.

158. Dufour E, Carcelain G, Gaudin C, Flament C, Avril MF, Faure F. Diversity of the cytotoxic melanoma-specific immune response: some CTL clones recognize autologous fresh tumor cells and not tumor cell lines. J Immunol. 1997;158(8):3787-95.

159. Tikochinski Y, Elias D, Steeg C, Marcus H, Kantorowitz M, Reshef T, et al. A shared TCR CDR3 sequence in NOD mouse autoimmune diabetes. Int Immunol. 1999;11(6):951-6.

160. Hogan LH, Wang M, Suresh M, Co DO, Weinstock JV, Sandor M. CD4+ TCR repertoire heterogeneity in Schistosoma mansoniinduced granulomas. J Immunol. 2002;169(11):6386-93.

161. Miles JJ, Silins SL, Brooks AG, Davis JE, Misko I, Burrows SR. T-cell grit: large clonal expansions of virus-specific CD8+ T cells can dominate in the peripheral circulation for at least 18 years. Blood. 2005;106(13):4412-3.

162. Aebischer T, Oehen S, Hengartner H. Preferential usage of Valpha 4 and $\mathrm{V}$ beta $10 \mathrm{~T}$ cell receptor genes by lymphocytic choriomeningitis virus glycoprotein-specific $\mathrm{H}-2 \mathrm{Db}$-restricted cytotoxic T cells. Eur J Immunol. 1990;20(3):523-31. https://doi. org/10.1002/eji.1830200310.

163. Zarour H, De Smet C, Lehmann F, Marchand M, Lethe B, Romero $\mathrm{P}$, et al. The majority of autologous cytolytic T-lymphocyte clones derived from peripheral blood lymphocytes of a melanoma patient recognize an antigenic peptide derived from gene Pmel17/gp100. J Invest Dermatol. 1996;107(1):63-7. 
164. Stanislawski T, Voss RH, Lotz C, Sadovnikova E, Willemsen RA, Kuball J, et al. Circumventing tolerance to a human MDM2derived tumor antigen by TCR gene transfer. Nat Immunol. 2001;2(10):962-70. https://doi.org/10.1038/ni1001-962.

165. Hiyane MI, Boscardin SB, Rodrigues MM. The non-palindromic adaptor-PCR method for the identification of the T-cell receptor genes of an interferon-gamma-secreting T-cell hybridomaspecific for trans-sialidase, an immunodominant Trypanosoma cruzi antigen. Braz J Med Biol Res. 2006;39(3):345-54.

166.• Emerson RO, WS DW, Vignali M, Gravley J, Hu JK, Osborne EJ, et al. Immunosequencing identifies signatures of cytomegalovirus exposure history and HLA-mediated effects on the T cell repertoire. Nat Genet. 2017;49(5):659-65. https://doi.org/10.1038/ng. 3822. This paper represents an essential step toward using immunosequencing data to differentiate type 1 diabetes patients from control subjects and ideally to predict disease progression. This paper identified TCRs associated with CMV serostatus, but the concept can likely be applied to type 1 diabetes research given sufficient samples and rescources.

167. Pathiraja V, Kuehlich JP, Campbell PD, Krishnamurthy B, Loudovaris T, Coates PT, et al. Proinsulin-specific, HLA-DQ8, and HLA-DQ8-transdimer-restricted CD4+ T cells infiltrate islets in type 1 diabetes. Diabetes. 2015;64(1):172-82. https://doi.org/ 10.2337/db14-0858.

168.• Michels AW, Landry LG, McDaniel KA, Yu L, CampbellThompson M, Kwok WW, et al. Islet-derived CD4 T cells targeting proinsulin in human autoimmune diabetes. Diabetes. 2017;66(3):722-34. https://doi.org/10.2337/db16-1025. This paper describes autoreactive $\mathbf{T}$ cell clones, including epitope reactivities, isolated from the pancreas of human type 1 diabetes organ donors.

169.• Babon JA, DeNicola ME, Blodgett DM, Crevecoeur I, Buttrick TS, Maehr R, et al. Analysis of self-antigen specificity of isletinfiltrating T cells from human donors with type 1 diabetes. Nat Med. 2016;22(12):1482-7. https://doi.org/10.1038/nm.4203. This paper describes autoreactive $\mathbf{T}$ cell clones, including epitope reactivities, isolated from the pancreas of human type 1 diabetes organ donors.

170. Insel RA, Dunne JL, Atkinson MA, Chiang JL, Dabelea D, Gottlieb PA, et al. Staging presymptomatic type 1 diabetes: a scientific statement of JDRF, the Endocrine Society, and the American Diabetes Association. Diabetes Care. 2015;38(10): 1964-74. https://doi.org/10.2337/dc15-1419. This is a consensus paper describing new clinical staging criteria for the diagnosis of type 1 diabetes with stage 1 disease being marked by multiple autoantibody positivity without dysglycemia and stage 2 representing the development of dysglycemia without overt symptomatic disease (i.e., type 1 diabetes diagnosis can be made prior to the requirement for insulin therapy).

171. Atkinson MA, Eisenbarth GS, Michels AW. Type 1 diabetes. Lancet. 2014;383(9911):69-82. https://doi.org/10.1016/S01406736(13)60591-7.

172. Eisenbarth GS, Type I. Diabetes mellitus. A chronic autoimmune disease. N Engl J Med. 1986;314(21):1360-8. https://doi.org/10. 1056/NEJM198605223142106.

173.• Kracht MJ, van Lummel M, Nikolic T, Joosten AM, Laban S, van der Slik AR, et al. Autoimmunity against a defective ribosomal insulin gene product in type 1 diabetes. Nat Med. 2017;23(4):5017. https://doi.org/10.1038/nm.4289. Seminal report of Defective Ribosomal Insulin Products (DRiPs) as novel autoantigens for type 1 diabetes.

174.• Delong T, Wiles TA, Baker RL, Bradley B, Barbour G, Reisdorph $\mathrm{R}$, et al. Pathogenic CD4 $\mathrm{T}$ cells in type 1 diabetes recognize epitopes formed by peptide fusion. Science. 2016;351(6274): 711-4. https://doi.org/10.1126/science.aad2791. Seminal report of hybrid insulin peptides (HIPs) as novel autoantigens for type 1 diabetes.

175.• Howie B, Sherwood AM, Berkebile AD, Berka J, Emerson RO, Williamson DW, et al. High-throughput pairing of T cell receptor alpha and beta sequences. Sci Transl Med. 2015;7(301):301ra131. https://doi.org/10.1126/scitranslmed.aac5624. This paper describes a key stride toward the ability to pair TCR alpha and beta chain sequences for TCR reconstruction.

176. Manual CSTU. http://www.clontech.com/xxclt ibcGetAttachment.jsp?cItemId=114424. Accessed 30 June 2017.

177. Taylor S, Yasuyama N, Farmer A.. A SMARTer approach to profiling the human T-cell receptor repertoire. 2016;196(1 Supplement):209.5.

178. Christley S, Levin M, Fonner J, Monson N, Rounds WH, Rubelt F et al. VDJPipe: a pre-processing pipeline for immune repertoire sequencing data. 2016;196(1 Supplement):209.26.

179. pRESTO. https://pypi.python.org/pypi/presto. Accessed 30 June 2017.

180. IgBLAST. ftp://ftp.ncbi.nih.gov/blast/executables/igblast/release/. Accessed 30 June 2017.

181. Ye J. An update on IgBLAST, a tool for Ig and TCR sequence analysis. 2016;196(1 Supplement):138.3.

182. MIGMAP. https://github.com/mikessh/migmap. Accessed 30 June 2017.

183. Decombinator. https://innate2adaptive.github.io/Decombinator/. Accessed 30 June 2017.

184. Thomas N, Heather J, Ndifon W, Shawe-Taylor J, Chain B. Decombinator: a tool for fast, efficient gene assignment in T-cell receptor sequences using a finite state machine. Bioinformatics. 2013;29(5):542-50. https://doi.org/10.1093/bioinformatics/ btt004.

185. Stubbington MJ, Lonnberg T, Proserpio V, Clare S, Speak AO, Dougan $\mathrm{G}$, et al. T cell fate and clonality inference from single-cell transcriptomes. Nat Methods. 2016;13(4):329-32. https://doi.org/ 10.1038/nmeth.3800.

186. TraCeR. https://github.com/teichlab/tracer. Accessed 30 June 2017.

187. Shugay M, Britanova OV, Merzlyak EM, Turchaninova MA, Mamedov IZ, Tuganbaev TR, et al. Towards error-free profiling of immune repertoires. Nat Methods. 2014;11(6):653-5. https:// doi.org/10.1038/nmeth.2960.

188. MiGEC. https://github.com/mikessh/migec. Accessed 30 June 2017.

189. Kuchenbecker L, Nienen M, Hecht J, Neumann AU, Babel N, Reinert K, et al. IMSEQ-a fast and error aware approach to immunogenetic sequence analysis. Bioinformatics. 2015;31(18): 2963-71. https://doi.org/10.1093/bioinformatics/btv309.

190. ImSeq. http://www.imtools.org/. Accessed 30 June 2017.

191. Gerritsen B, Pandit A, Andeweg AC, de Boer RJ. RTCR: a pipeline for complete and accurate recovery of $\mathrm{T}$ cell repertoires from high throughput sequencing data. Bioinformatics. 2016;32(20): 3098-106. https://doi.org/10.1093/bioinformatics/btw339.

192. RTCR. https://github.com/uubram/RTCR. Accessed 30 June 2017.

193. Bolotin DA, Poslavsky S, Mitrophanov I, Shugay M, Mamedov IZ, Putintseva EV et al. MiXCR: software for comprehensive adaptive immunity profiling. Nat Methods. 2015;12(5): 380-1. https://doi.org/10.1038/nmeth.3364.

194. MiXCR. https://mixcr.readthedocs.io/en/latest/quickstart.html. Accessed 30 June 2017.

195. Toby IT, Levin MK, Salinas EA, Christley S, Bhattacharya S, Breden F, et al. VDJML: a file format with tools for capturing the results of inferring immune receptor rearrangements. BMC Bioinformatics. 2016;17(Suppl 13):333. https://doi.org/10.1186/ s12859-016-1214-3. 
196. VDJserver. https://vdjserver.org. Accessed 30 June 2017.

197. Robins HS, Campregher PV, Srivastava SK, Wacher A, Turtle CJ, Kahsai O, et al. Comprehensive assessment of T-cell receptor $\beta$ chain diversity in $\alpha \beta$ T cells. Blood. 2009;114(19):4099-107. https://doi.org/10.1182/blood-2009-04-217604.

198. immunoSEQ. http://www.adaptivebiotech.com/immunoseq/. Accessed 30 June 2017.

199. iPair. http://www.irepertoire.com/ipair. Accessed 30 June 2017.

200. Bolen CR, Rubelt F, Vander Heiden JA, Davis MM. The repertoire dissimilarity index as a method to compare lymphocyte receptor repertoires. BMC Bioinformatics. 2017;18(1):155. https://doi.org/ 10.1186/s12859-017-1556-5.

201. RDI. https://bitbucket.org/cbolen1/rdicore/. Accessed 30 June 2017.

202. Dash P, Fiore-Gartland AJ, Hertz T, Wang GC, Sharma S, Souquette A, et al. Quantifiable predictive features define epitope-specific T cell receptor repertoires. Nature. 2017; https:// doi.org/10.1038/nature22383.

203. TCRdist. https://github.com/phbradley/tcr-dist. Accessed 30 June 2017.

204. iRweb. http://www.irepertoire.com/irweb. Accessed 30 June 2017

205. Loupe. https://support.10xgenomics.com/genome-exome/ software/visualization/latest/what-is-loupe. Accessed 30 June 2017.

206. Nazarov VI, Pogorelyy MV, Komech EA, Zvyagin IV, Bolotin DA, Shugay M, et al. tcR: an R package for T cell receptor repertoire advanced data analysis. BMC Bioinformatics. 2015;16:175. https://doi.org/10.1186/s12859-015-0613-1.

207. tcR. https://imminfo.github.io/tcr. Accessed 30 June 2017.

208. Shugay M, Bagaev DV, Turchaninova MA, Bolotin DA, Britanova OV, Putintseva EV, et al. VDJtools: unifying postanalysis of $\mathrm{T}$ cell receptor repertoires. PLoS Comput Biol. 2015;11(11):e1004503. https://doi.org/10.1371/journal.pcbi. 1004503.

209. VDJtools. https://vdjtools-doc.readthedocs.io/en/latest/intro.html. Accessed 30 June 2017.

210. Bagaev DV, Zvyagin IV, Putintseva EV, Izraelson M, Britanova OV, Chudakov DM, et al. VDJviz: a versatile browser for immunogenomics data. BMC Genomics. 2016;17:453. https:// doi.org/10.1186/s12864-016-2799-7.

211. VDJviz. https://github.com/antigenomics/vdjviz. Accessed 30 June 2017.

212. Cao X, Wa Q, Wang Q, Li L, Liu X, An L, et al. High throughput sequencing reveals the diversity of TRB-CDR3 repertoire in patients with psoriasis vulgaris. Int Immunopharmacol. 2016;40: 487-91. https://doi.org/10.1016/j.intimp.2016.10.004.

213. Guo C, Wang Q, Cao X, Yang Y, Liu X, An L, et al. Highthroughput sequencing reveals immunological characteristics of the TRB-/IgH-CDR3 region of umbilical cord blood. J Pediatr. 2016;176:69-78.e1. https://doi.org/10.1016/j.jpeds.2016.05.078.

214. Fahnrich A, Krebbel M, Decker N, Leucker M, Lange FD, Kalies $\mathrm{K}$, et al. ClonoCalc and ClonoPlot: immune repertoire analysis from raw files to publication figures with graphical user interface. BMC Bioinformatics. 2017;18(1):164. https://doi.org/10.1186/ s12859-017-1575-2.

215. Kukurba K, Montgomery S. RNA sequencing and analysis. Cold Spring Harb Protoc. 2015;2015(11):951-69.

216. Newell EW, Davis MM. Beyond model antigens: highdimensional methods for the analysis of antigen-specific T cells. Nat Biotechnol. 2014;32(2):149-57. https://doi.org/10.1038/nbt. 2783.

217.• Zheng GXY, Terry JM, Belgrader P, Ryvkin P, Bent ZW, Wilson $\mathrm{R}$, et al. Massively parallel digital transcriptional profiling of single cells. Nat Commun. 2017;8:14049. https://doi.org/10.1038/ ncomms 14049 . This paper reports single-cell immunosequencing which will be an imperative step toward identifying cell function/phenotype along with TCR clone/ reactivity.

218. Ziegler AG, Rewers M, Simell O, Simell T, Lempainen J, Steck A, et al. Seroconversion to multiple islet autoantibodies and risk of progression to diabetes in children. JAMA. 2013;309(23):2473-9. https://doi.org/10.1001/jama.2013.6285.

219. Lebastchi J, Herold KC. Immunologic and metabolic biomarkers of beta-cell destruction in the diagnosis of type 1 diabetes. Cold Spring Harb Perspect Med. 2012;2(6):a007708. https://doi.org/10. 1101/cshperspect.a007708.

220. Wu J, Jia S, Wang C, Zhang W, Liu S, Zeng X, et al. Minimal residual disease detection and evolved IGH clones analysis in acute B lymphoblastic leukemia using IGH deep sequencing. Front Immunol. 2016;7:403. https://doi.org/10.3389/fimmu. 2016.00403. This paper supports the notion that immunosequencing offers sufficient specificity and sensitivity to potentially detect minimal resisual autoimmune disease (similar to monitoring MRD in leukemia patients). This suggests that immunosequencing could be used to monitor patients' response to therapy and determine if a redose may be necessary.

221. Weng WK, Armstrong R, Arai S, Desmarais C, Hoppe R, Kim YH. Minimal residual disease monitoring with high-throughput sequencing of $\mathrm{T}$ cell receptors in cutaneous $\mathrm{T}$ cell lymphoma. Sci Transl Med. 2013;5(214):214ra171. https://doi.org/10.1126/ scitranslmed.3007420.

222. Logan AC, Vashi N, Faham M, Carlton V, Kong K, Buno I, et al. Immunoglobulin and $\mathrm{T}$ cell receptor gene high-throughput sequencing quantifies minimal residual disease in acute lymphoblastic leukemia and predicts post-transplantation relapse and survival. Biol Blood Marrow Transplant. 2014;20(9):1307-13. https://doi. org/10.1016/j.bbmt.2014.04.018.

223. Faham M, Zheng J, Moorhead M, Carlton VE, Stow P, CoustanSmith E, et al. Deep-sequencing approach for minimal residual disease detection in acute lymphoblastic leukemia. Blood. 2012;120(26):5173-80. https://doi.org/10.1182/blood-2012-07444042.

224. von Herrath M, Sanda S, Herold K. Type 1 diabetes as a relapsingremitting disease? Nat Rev Immunol. 2007;7(12):988-94. https:// doi.org/10.1038/nri2192.

225. Thelin MA, Kissler S, Vigneault F, Watters AL, White D, Koshy $\mathrm{ST}$, et al. In vivo enrichment of diabetogenic T cells. Diabetes. 2017; https://doi.org/10.2337/db16-0946.

226. Belzer FO, Schweizer RT, Cho S, Cochrum KC, Moberg A, Kountz SL. Efficacy of antilymphocyte globulin in cadaver renal transplantation. Surg Forum. 1971;22:223-4.

227. Birtch AG, Carpenter CB, Tilney NL, Hampers CL, Hager FB, Levine L, et al. Controlled clinical trial of antilymphocyte globulin in human renal allografts. Transplant Proc. 1971;3(1):762-5.

228. Griepp RB, Stinson EB, Dong E Jr, Phillips RC, Morrell RM, Shumway NE. Use of antithymocyte globulin in human heart transplantation. Circulation. 1972;45(5 Suppl 1):I147-53.

229. Storb R, Blume KG, O'Donnell MR, Chauncey T, Forman SJ, Deeg HJ, et al. Cyclophosphamide and antithymocyte globulin to condition patients with aplastic anemia for allogeneic marrow transplantations: the experience in four centers. Biol Blood Marrow Transplant. 2001;7(1):39-44. https://doi.org/10.1053/ bbmt.2001.v7.pm11215697.

230. Yussim A, Shapira Z. Single-bolus high-dose ATG for prophylaxis of rejection in renal transplantation - a prospective, randomized study. Transpl Int. 2000;13(Suppl 1):S293-4.

231. Bhise V, Dhib-Jalbut S. Further understanding of the immunopathology of multiple sclerosis: impact on future treatments. Expert Rev Clin Immunol. 2016;12(10):1069-89. https://doi.org/10. 1080/1744666x.2016.1191351. 
232. Semerano L, Minichiello E, Bessis N, Boissier MC. Novel immunotherapeutic avenues for rheumatoid arthritis. Trends Mol Med. 2016;22(3):214-29. https://doi.org/10.1016/j.molmed.2016.01. 005 .

233. Daifotis AG, Koenig S, Chatenoud L, Herold KC. Anti-CD3 clinical trials in type 1 diabetes mellitus. Clin Immunol. 2013;149(3): 268-78. https://doi.org/10.1016/j.clim.2013.05.001.

234. Long SA, Rieck M, Sanda S, Bollyky JB, Samuels PL, Goland R, et al. Rapamycin/IL-2 combination therapy in patients with type 1 diabetes augments Tregs yet transiently impairs beta-cell function. Diabetes. 2012; https://doi.org/10.2337/db12-0049.

235. Gottlieb PA, Quinlan S, Krause-Steinrauf H, Greenbaum CJ, Wilson DM, Rodriguez H, et al. Failure to preserve beta-cell function with mycophenolate mofetil and daclizumab combined therapy in patients with new- onset type 1 diabetes. Diabetes Care. 2010;33(4):826-32. https://doi.org/10.2337/dc09-1349.

236. Orban T, Bundy B, Becker DJ, DiMeglio LA, Gitelman SE, Goland R, et al. Co-stimulation modulation with abatacept in patients with recent-onset type 1 diabetes: a randomised, doubleblind, placebo-controlled trial. Lancet. 2011;378(9789):412-9. https://doi.org/10.1016/S0140-6736(11)60886-6.

237. Ehlers MR, Nepom GT. Immune-directed therapy for type 1 diabetes at the clinical level: the Immune Tolerance Network (ITN) experience. Rev Diabet Stud. 2012;9(4):359-71. https://doi.org/ 10.1900/rds.2012.9.359.

238. Moran A, Bundy B, Becker DJ, DiMeglio LA, Gitelman SE, Goland R, et al. Interleukin-1 antagonism in type 1 diabetes of recent onset: two multicentre, randomised, double-blind, placebocontrolled trials. Lancet. 2013;381(9881):1905-15. https://doi. org/10.1016/S0140-6736(13)60023-9.

239. Feutren G, Assan R, Karsenty G, Du Rostu H, Sirmai J, Papos L, et al. Cyclosporin increases the rate and length of remissions in insulin-dependent diabetes of recent onset: results of a multicentre double-blind trial. Lancet. 1986;328(8499):119-24. https://doi. org/10.1016/S0140-6736(86)91943-4.

240. Assan R, Feutren G, Debray-Sachs M, Quiniou-Debrie MC, Laborie C, Thomas G, et al. Metabolic and immunological effects of cyclosporin in recently diagnosed type 1 diabetes mellitus. Lancet. 1985;1(8420):67-71.

241. Sobel DO, Henzke A, Abbassi V. Cyclosporin and methotrexate therapy induces remission in type 1 diabetes mellitus. Acta Diabetol. 2010;47(3):243-50. https://doi.org/10.1007/s00592010-0188-2.

242. Hagopian W, Ferry RJ Jr, Sherry N, Carlin D, Bonvini E, Johnson $\mathrm{S}$, et al. Teplizumab preserves C-peptide in recent-onset type 1 diabetes: two-year results from the randomized, placebocontrolled Protege trial. Diabetes. 2013;62(11):3901-8. https:// doi.org/10.2337/db13-0236.

243. Herold KC, Gitelman SE, Ehlers MR, Gottlieb PA, Greenbaum CJ, Hagopian W, et al. Teplizumab (anti-CD3 mAb) treatment preserves C-peptide responses in patients with new-onset type 1 diabetes in a randomized controlled trial: metabolic and immunologic features at baseline identify a subgroup of responders. Diabetes. 2013;62(11):3766-74. https://doi.org/10.2337/db130345.

244. Herold KC, Gitelman SE, Willi SM, Gottlieb PA, Waldron-Lynch F, Devine L, et al. Teplizumab treatment may improve C-peptide responses in participants with type 1 diabetes after the new-onset period: a randomised controlled trial. Diabetologia. 2013;56(2): 391-400. https://doi.org/10.1007/s00125-012-2753-4.

245. Orban T, Bundy B, Becker DJ, Dimeglio LA, Gitelman SE, Goland R, et al. Costimulation modulation with abatacept in patients with recent-onset type 1 diabetes: follow-up 1 year after cessation of treatment. Diabetes Care. 2014;37(4):1069-75. https://doi.org/10.2337/dc13-0604.
246. Haller MJ, Gitelman SE, Gottlieb PA, Michels AW, Rosenthal SM, Shuster JJ, et al. Anti-thymocyte globulin/G-CSF treatment preserves $\beta$ cell function in patients with established type 1 diabetes. J Clin Invest. 2015;125(1):448-55. https://doi.org/10.1172/ JCI78492.

247. Haller MJ, Gitelman SE, Gottlieb PA, Michels AW, Perry DJ, Schultz AR, et al. Antithymocyte globulin plus G-CSF combination therapy leads to sustained immunomodulatory and metabolic effects in a subset of responders with established type 1 diabetes. Diabetes. 2016;65(12):3765-75. https://doi.org/10.2337/db16-0823.

248. Cabrera SM, Wang X, Chen YG, Jia S, Kaldunski ML, Greenbaum CJ, et al. Interleukin-1 antagonism moderates the inflammatory state associated with type 1 diabetes during clinical trials conducted at disease onset. Eur J Immunol. 2016;46(4): 1030-46. https://doi.org/10.1002/eji.201546005.

249. Gitelman SE, Gottlieb PA, Felner EI, Willi SM, Fisher LK, Moran A, et al. Antithymocyte globulin therapy for patients with recentonset type 1 diabetes: 2 year results of a randomised trial. Diabetologia. 2016; https://doi.org/10.1007/s00125-016-3917-4.

250. Rigby MR, Harris KM, Pinckney A, DiMeglio LA, Rendell MS, Felner EI, et al. Alefacept provides sustained clinical and immunological effects in new-onset type 1 diabetes patients. J Clin Invest. 2015;125(8):3285-96. https://doi.org/10.1172/jci81722.

251. Voltarelli JC, Couri CE, Stracieri AB, Oliveira MC, Moraes DA, Pieroni F, et al. Autologous nonmyeloablative hematopoietic stem cell transplantation in newly diagnosed type 1 diabetes mellitus. JAMA. 2007;297(14):1568-76. https://doi.org/10.1001/jama. 297.14.1568

252. D'Addio F, Valderrama Vasquez A, Ben Nasr M, Franek E, Zhu D, Li L, et al. Autologous nonmyeloablative hematopoietic stem cell transplantation in new-onset type 1 diabetes: a multicenter analysis. Diabetes. 2014;63(9):3041-6. https://doi.org/10.2337/ db14-0295.

253. Mohty M. Mechanisms of action of antithymocyte globulin: T-cell depletion and beyond. Leukemia. 2007;21(7):1387-94. https:// doi.org/10.1038/sj.leu.2404683.

254. Bendall LJ, Bradstock KF. G-CSF: from granulopoietic stimulant to bone marrow stem cell mobilizing agent. Cytokine Growth Factor Rev. 2014;25(4):355-67. https://doi.org/10.1016/j.cytogfr. 2014.07.011.

255. Jaspers JE, Brentjens RJ. Development of CAR T cells designed to improve antitumor efficacy and safety. Pharmacol Ther. 2017; https://doi.org/10.1016/j.pharmthera.2017.03.012.

256. Scarfo I, Maus MV. Current approaches to increase CAR T cell potency in solid tumors: targeting the tumor microenvironment. J Immunother Cancer. 2017;5:28. https://doi.org/10.1186/s40425017-0230-9.

257. Lee DW, Kochenderfer JN, Stetler-Stevenson M, Cui YK, Delbrook C, Feldman SA, et al. T cells expressing CD19 chimeric antigen receptors for acute lymphoblastic leukaemia in children and young adults: a phase 1 dose-escalation trial. Lancet. 2015;385(9967):517-28. https://doi.org/10.1016/s01406736(14)61403-3.

258. Kochenderfer JN, Wilson WH, Janik JE, Dudley ME, StetlerStevenson M, Feldman SA, et al. Eradication of B-lineage cells and regression of lymphoma in a patient treated with autologous $\mathrm{T}$ cells genetically engineered to recognize CD19. Blood. 2010;116(20):4099-102. https://doi.org/10.1182/blood-2010-04281931.

259. Zhao Y, Moon E, Carpenito C, Paulos CM, Liu X, Brennan AL, et al. Multiple injections of electroporated autologous T cells expressing a chimeric antigen receptor mediate regression of human disseminated tumor. Cancer Res. 2010;70(22):9053-61. https:// doi.org/10.1158/0008-5472.can-10-2880.

260. Birkholz K, Hombach A, Krug C, Reuter S, Kershaw M, Kampgen E, et al. Transfer of mRNA encoding recombinant 
immunoreceptors reprograms CD4+ and CD8+ T cells for use in the adoptive immunotherapy of cancer. Gene Ther. 2009;16(5): 596-604. https://doi.org/10.1038/gt.2008.189.

261. Brusko TM, Koya RC, Zhu S, Lee MR, Putnam AL, McClymont SA, et al. Human antigen-specific regulatory $\mathrm{T}$ cells generated by T cell receptor gene transfer. PLoS One. 2010;5(7):e11726. https:// doi.org/10.1371/journal.pone.0011726.

262. Gravano DM, Vignali DA. The battle against immunopathology: infectious tolerance mediated by regulatory T cells. Cell Mol Life Sci. 2012;69(12):1997-2008. https://doi.org/10.1007/s00018011-0907-z.

263. Vanderlugt CL, Miller SD. Epitope spreading in immunemediated diseases: implications for immunotherapy. Nat Rev Immunol. 2002;2(2):85-95. https://doi.org/10.1038/nri724.
264. Smith CE, Miller SD. Multi-peptide coupled-cell tolerance ameliorates ongoing relapsing EAE associated with multiple pathogenic autoreactivities. J Autoimmun. 2006;27(4):218-31. https:// doi.org/10.1016/j.jaut.2006.12.002.

265. Getts DR, Martin AJ, McCarthy DP, Terry RL, Hunter ZN, Yap WT, et al. Microparticles bearing encephalitogenic peptides induce T-cell tolerance and ameliorate experimental autoimmune encephalomyelitis. Nat Biotechnol. 2012;30(12):1217-24. https://doi.org/10.1038/nbt.2434.

266. Jones BS, Lamb LS, Goldman F, Di Stasi A. Improving the safety of cell therapy products by suicide gene transfer. Front Pharmacol. 2014;5:254. https://doi.org/10.3389/fphar.2014.00254. 